\title{
Multiple ecosystem services from field margin vegetation for ecological sustainability in agriculture: Scientific evidence and knowledge gaps
}

\author{
Prisila A Mkenda ${ }^{1,2,3}$, Patrick A Ndakidemi ${ }^{1}$, Ernest Mbega ${ }^{1}$, Philip C Stevenson ${ }^{4,5}$, Sarah EJ Arnold ${ }^{4}$, Geoff M \\ Gurr $^{2,6}$, Steven R Belmain ${ }^{\text {Corresp. } 4}$ \\ ${ }^{1}$ Department of Sustainable Agriculture, Biodiversity and Ecosystems Management, Nelson Mandela African Institution of Science and Technology, \\ Arusha, Tanzania \\ 2 School of Agricultural and Wine Sciences, Charles Sturt University, NSW, Australia \\ 3 Department of Biosciences, Sokoine University of Agriculture, Morogoro, Tanzania \\ 4 Natural Resources Institute, University of Greenwich, Chatham Maritime, Kent, United Kingdom \\ 5 Royal Botanic Gardens, Kew, Richmond, Surrey, United Kingdom \\ 6 Institute of Applied Ecology, Fujian Agriculture and Forestry University, Fuzhou, China \\ Corresponding Author: Steven R Belmain \\ Email address: s.r.belmain@greenwich.ac.uk
}

Background. Field margin and non-crop vegetation in agricultural systems are potential ecosystem services providers because they offer semi-natural habitats for both below and above ground animal groups such as soil organisms, small mammals, birds and arthropods that are service supplying units. They are considered as a target area for enhancing farm biodiversity.

Methodology. To explore the multiple potential benefits of these semi-natural habitats and to identify research trends and knowledge gaps in the world, a review was carried out following the Preferred Reporting Items for Systematic Reviews and Meta-Analyses guidelines. A total of 235 publications from the year 2000 to 2016 in the Scopus and Web of Science databases were reviewed.

Results. The literature showed an increasing trend in the number of published articles over time with European studies leading in the proportion of studies conducted, followed by North America, Asia, South America, Africa and Australia. Several functional groups of organisms were studied from field margin and non-crop vegetation around agricultural lands including natural enemies (37\%), insect pests $(22 \%)$, birds (17\%), pollinators (16\%), soil macro fauna (4\%) and small mammals (4\%). Ecosystem services derived from the field margin included natural pest regulation, pollination, nutrient cycling and reduced offsite erosion. Some field margin plants were reported to host detrimental crop pests, a major ecosystem disservice, potentially leading to increased pest infestation in the field.

Conclusion. The majority of studies revealed the importance of field margin and non-crop vegetation around arable fields in enhancing ecosystem biodiversity. Promotion of field margin plants that selectively enhance the population of beneficial organisms would support sustainable food security rather than simply boosting plant diversity. Our analyses also highlight that agro-ecological studies remain largely overlooked in some regions. 


\section{Multiple ecosystem services from field margin}

\section{2 vegetation for ecological sustainability in agriculture:}

\section{Scientific evidence and knowledge gaps}

4

5

6

7

8

9

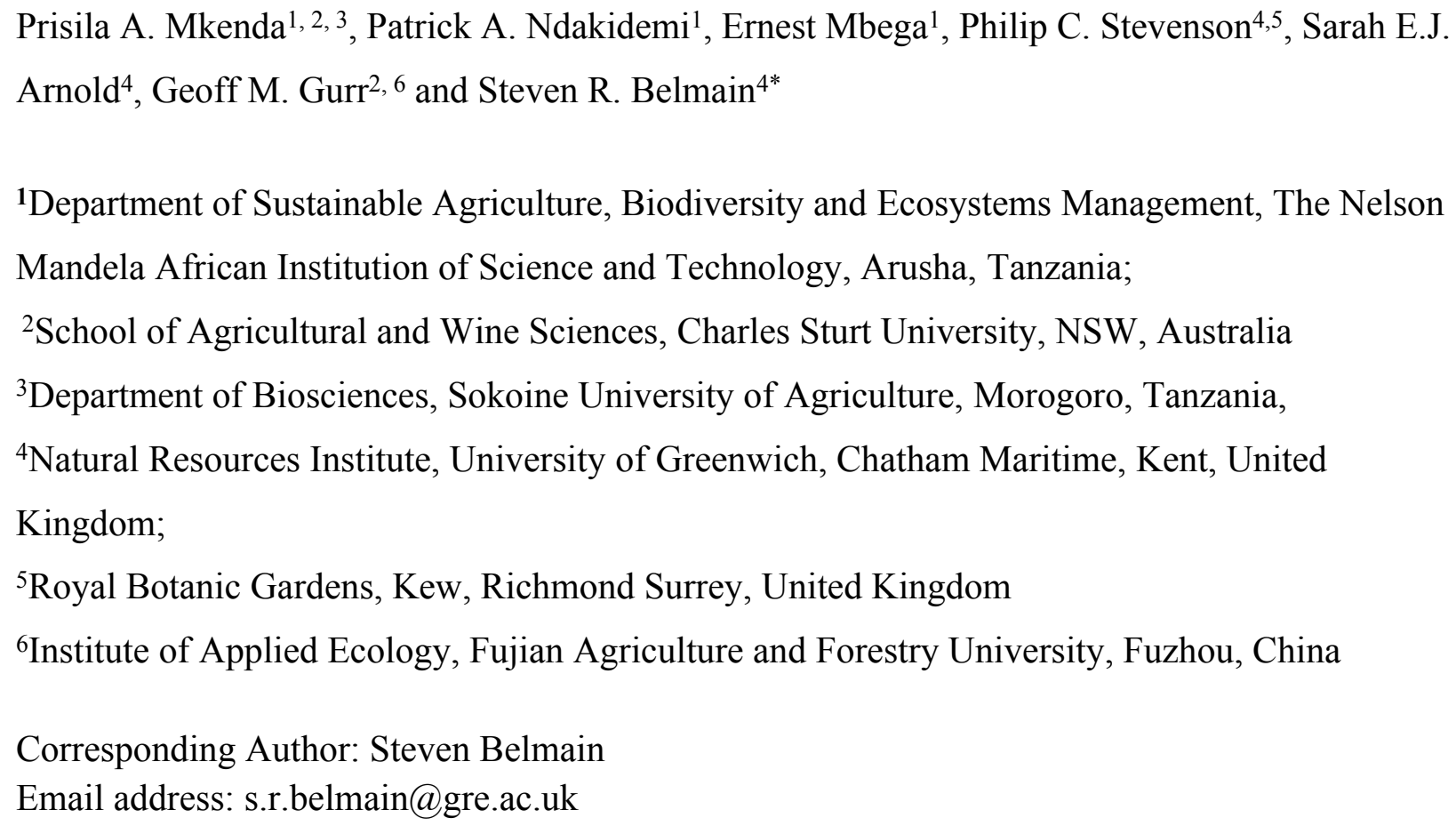




\section{Abstract}

22 Background. Field margin and non-crop vegetation in agricultural systems are potential

23

24

25

26

27 ecosystem services providers because they offer semi-natural habitats for both below and above ground animal groups such as soil organisms, small mammals, birds and arthropods that are service supplying units. They are considered as a target area for enhancing farm biodiversity. Methodology. To explore the multiple potential benefits of these semi-natural habitats and to identify research trends and knowledge gaps in the world, a review was carried out following the Preferred Reporting Items for Systematic Reviews and Meta-Analyses guidelines. A total of 235 publications from the year 2000 to 2016 in the Scopus and Web of Science databases were reviewed.

Results. The literature showed an increasing trend in the number of published articles over time with European studies leading in the proportion of studies conducted, followed by North America, Asia, South America, Africa and Australia. Several functional groups of organisms were studied from field margin and non-crop vegetation around agricultural lands including natural enemies $(37 \%)$, insect pests $(22 \%)$, birds $(17 \%)$, pollinators $(16 \%)$, soil macrofauna $(4 \%)$ and small mammals (4\%). Ecosystem services derived from the field margin included natural pest regulation, pollination, nutrient cycling and reduced offsite erosion. Some field margin plants were reported to host detrimental crop pests, a major ecosystem dis-service, potentially leading to increased pest infestation in the field.

Conclusion. The majority of studies revealed the importance of field margin and non-crop vegetation around arable fields in enhancing ecosystem biodiversity. Promotion of field margin plants that selectively enhance the population of beneficial organisms would support sustainable food security rather than simply boosting plant diversity. Our analyses also highlight that agroecological studies remain largely overlooked in some regions.

\section{Introduction}

The world population is currently 7.7 billion (UN, 2019) and it is projected to grow to 9.5 billion in 2050 (Lal, 2015) and more than 12 billion by the end of the $21^{\text {st }}$ century, with most of the increase expected to occur in Africa (Gerland et al., 2014). Consequently, food demand will escalate (Valin et al., 2014); however, agricultural intensification through monocultured cropping systems is not a promising strategy for future needs due to adverse environmental effects (Jonsson et al., 2012; Robinson \& Sutherland, 2002). In addition, conversion of natural 
53 and semi-natural habitats to arable farms with increased chemical inputs are among the threats to 54 sustainable agriculture (Meehan et al., 2011). Agricultural intensification has replaced much of 55 the native vegetation in the world, and it is estimated about $70 \%$ of tropical land is under 56 agriculture and/or pasture modified systems (McNeely \& Scherr, 2003; Ordway, Asner \& 57 Lambin, 2017). Intensive agricultural systems are associated with negative environmental 58 impacts, including decreased biodiversity of wild plants and animals. This can lead to increased 59 pest damage as a result of decline in natural pest control often caused by increased chemical 60 inputs (Jonsson et al., 2012) whilst promoting pest abundance through monoculture cropping systems (Meehan et al., 2011). Various approaches can be taken to mitigate these impacts, including the adoption of intercropping (Martin-Guay et al., 2018). However, the focus on field manipulation might be insufficient to increase biodiversity of the farmland throughout the year unless it is supplemented with proper management of the field margins (Wiggers et al., 2016).

In most farmland, field margin vegetation may represent the key semi-natural habitat available to enhance biodiversity. Field margin abundance, location and management practices can determine the environmental benefits obtained. Field margins can be managed for provision of multiple ecosystem services such as medicinal products (Rigat et al., 2009), reduced soil erosion and/or nutrients runoff (Sheppard et al., 2006), increased litter decomposition (Smith et al., 2009), and reduced air and water pollution from runoff and pesticide spray drift (Sheppard et al., 2006). Other benefits include increased biodiversity of different plant and animal groups with various environmental benefits. Field margins at the boundary of sensitive features like watercourses can provide additional environmental benefits like protection of water sources from soil erosion and agricultural pollutants compared with field margin that separates two arable farms (Hackett \& Lawrence, 2014). In addition, field margins can serve as habitat corridors to connect other remnant semi-natural habitat fragments such as woodlands (Marshall \& Moonen, 2002). In terms of management, field margins can promote more diverse organisms when there is also reduced pesticide use, tillage and enhanced crop cover compared with a conventionally managed crop (Vickery, Feber \& Fuller, 2009). Field margins can be designed to provide a particular benefit for a particular group of organisms. Increased numbers of aerial insects, which are the target food for Black-tailed Godwit chicks, can be supported through management of field margins of 
84 Woodcock et al. (2008) observed positive responses of carabid beetle distribution and diversity 85 as a result of different management levels of the field margins that increased sward architectural

86

87

88 89

90

91 92 93 94 95 96 97 98 99

100 101

102

103

104

105

106

107

108

109

110

111

112

113

114 complexity through combinations of inorganic fertilizers, grazing and cutting at different heights and time. Ramsden et al. (2014) reported on the potential of field margins for food provisioning, overwintering sites and hosts to various predators and parasitoids for enhanced biological control services in agro-ecosystems. Several studies have reported on the importance of field margin management in arable fields for the provision of foraging habitats, nesting sites, food resources and shelter for invertebrates and vertebrates (Bianchi, Booij \& Tscharntke, 2006; Gurr, Wratten \& Luna, 2003; Landis, Wratten \& Gurr, 2000; Marshall, 2004). These benefits can be particularly important after disturbances caused by agricultural practices like tillage, pesticide application and harvesting (Lee, Menalled \& Landis, 2001). Field margin establishment and management is one of the affordable measure by a majority of the farmers due to the associated multiple benefits including biodiversity, conservation and functional values (Moorman et al., 2013). Understanding the various benefits of field margin and non-crop vegetation in agriculture and environment is particularly important for proper management.

Field margins comprise of native and /or non-native plants that separate the cropped area from hedgerows or other off crop features. Broadly, field margins are grouped under two major categories; cropped field margins and uncropped field margins (Vickery, Feber \& Fuller, 2009). Cropped field margins contain sown arable crops that are identified using ecological and conservation principles. Margins can be managed using the existing field operations where the cultivated strip land is left to regenerate naturally or planting strips to provide food resources to insects. Uncropped field margins are set aside margins that are sown (with wild seed mixtures) or left to regenerate naturally without human manipulation. Both cropped and uncropped field margins can be maintained in various ways including cutting to reduce shading and invasion to the field.

Field margins may provide various environmental benefits depending on the establishment and management method employed (Bowie et al., 2014; Fritch et al., 2011; Huallacháin et al., 2014; Meek et al., 2002; Vickery, Carter \& Fuller, 2002; Walker et al., 2007). For example, uncropped margin types were found to be more capable of supporting high plant density compared with 
115 cropped field margins, due to the effect of competition from the crop (Walker et al., 2007).

116 Multiple benefits may be achieved where different margin types are incorporated at the same

117 farm because no single field margin is capable of providing the required food and habitat

118 resources to all plants and animal groups (Olson \& Wäckers, 2007; Vickery, Feber \& Fuller,

119 2009; Woodcock et al., 2009). Establishment and management method employed to the field

120 margin in arable farmland (Figure 1) may significantly influence the long term conservation

121 values (Smith et al., 2010). Therefore, the intention of integrating agronomic and biodiversity

122 objectives may widely be achieved through field margin establishment and management.

123

124 Figure 1: Field margin management practices, undisturbed (left) and disturbed (right).

125 Undisturbed field margin vegetation around agricultural lands are useful in provision of nectar

126 and habitat for beneficial arthropods thereby enhancing ecosystem services. Disturbed or cleared

127 field margins are less efficient in enhancing beneficial arthropods

128

129

130

131

132

133

\section{Survey methodology}

The objective of the study was to analyse the multifunctional role of field margin and non-crop vegetation in agriculture and to identify research trends and knowledge gaps in the world by review of published articles. The review was carried out following the Preferred Reporting Items for Systematic Reviews and Meta-Analyses guidelines (Moher et al., 2009) and focused on both geographical and temporal distribution of the studies published in the year 2000 to 2016 . The literature was accessed from Scopus scientific database using a series of key words: "field margin*" OR "non crop*" OR "margin plant*" OR "border plant*" OR "margin vegetation*" in

the subject area of agricultural, biological and environmental sciences.

A total of 1,153 research articles, 63 review papers and 54 conference papers containing the key words in title, abstract or keywords were found. These items were trimmed to 204 research articles, 5 review papers and 8 conference papers, making a total of 217 publications based on the criterion that the search terms appeared in the title. A further search using the same key words in the title from Web of Science database led to 197 research articles and 10 proceedings papers. These publications were then crosschecked between the two databases to avoid duplications, adding 8 research articles and 10 conference papers/proceedings as the only 
146 additional materials from the Web of Science database. This brought the total number of

147 publications considered in this review to 235. Detailed analysis of the literature was done to

148 extract information on the spatial data (study location), animal groups studied, and ecosystem

149 services and disservices derived from the field margin biodiversity. Information on the impact of

150 farming and management practices to the field margin flora and diversity was also analysed.

151

152 Results and discussion

153 There has been a marked increase in the numbers of publications from 2000 to 2016 . These

154 studies were largely conducted in European countries followed by North America then Asia,

155 South America, Africa and Australia. The animal groups studied include arthropod natural

156 enemies, insect pests, pollinators, birds, soil macrofauna and small mammals (Figure 2).

157

158 Figure 2: Animal groups that benefit from the field margin and non-crop vegetation around 159 agricultural lands

160

161

Other studies assessed the environmental factors (such as landscape structure, hedge stand types

162 and site conditions) that determine the flora composition of field margins (Guiller et al., 2016; Sitzia et al., 2013; Sitzia, Dainese \& McCollin, 2014; Wrzesień \& Denisow, 2016; Street et al., 164 2015). The role of field margins in preventing soil erosion (Ali \& Reineking, 2016; Sheppard et al., 2006) and soil carbon losses ( D'Acunto, Semmartin \& Ghersa, 2014) were also studied. It was further reported that field margins are ecologically affected by the agronomic and management practices employed within the crop land like pesticide, herbicides and fertilizer application ((Alignier \& Baudry, 2015; Hahn, Lenhardt \& Brühl, 2014; Kang et al., 2013; Schmitz, Schäfer \& Brühl, 2013; Schmitz, Hahn \& Brühl, 2014a; Schmitz, Schäfer \& Brühl, 2014b). The ecological effects of field margin plants to weed infestation in the field (De Cauwer et al., 2008; Reberg-Horton et al., 2011; Tarmi, Helenius \& Hyvönen, 2011) and organic matter

172 decomposition (Smith et al., 2009) were also investigated. 
177 promoting ecosystem services like natural pest regulation, pollination and nutrient cycling. These

178 three ecological benefits of the field margin may be categorized as biodiversity value,

179 conservation value and functional value respectively. This is apparent from the literature

180 reviewed as most of the studies were related to biodiversity and functional values while only a

181 few focussed on conservation value, particularly habitat and food resource provision to rare and

182 endangered bird species.

183

\subsubsection{Enhancement of arthropod natural enemies and biological control of insect pests}

From the literature review, natural enemies were the most studied in terms of the number of

186

publications compared with other groups. The most studied natural enemies were spiders and

187

ground beetles (Carabidae) since these organisms are regarded as biological indicators in

188

biodiversity and conservation assessments as well as indicators of change in terrestrial

189 ecosystems (Perner \& Malt, 2003). Other natural enemies studied were ladybirds (Coccinellidae), hover flies (Syrphidae), tachinid flies (Tachinidae), predatory bugs (including Miridae, Reduviidae), parasitoid species of various families (Chalcidoidea, Ichneumonoidea, Chrysidoidea and Proctotrupoidea), Neuroptera and ants (Formicidae) (Anderson et al., 2013; Balzan, Bocci \& Moonen, 2016; Bowie et al., 2014). The studies supported hypotheses about the importance of increased diversity of field margin plants and landscape complexity to the populations of different natural enemy groups and pest control (Atakan, 2010; Pluess et al., 2010, Rouabah et al., 2015; Torretta \& Poggio, 2013; Werling \& Gratton, 2008). Strips and borders of non-crop vegetation were found to increase the abundance and diversity of spider communities and other natural enemies (Amaral et al., 2016; Ditner et al., 2013; Gurr et al., 2016; Pluess et al., 2010). Field margin plants such as trees and shrubs are considered as refuge sites for increased population of predatory insects (Burgio et al., 2004). It was found that field margins with several plant species at local and landscape level are effective in managing pests compared with simplified field margins (Bischoff et al., 2016). Field margins with sufficient flowering plants act as reservoirs of beneficial insects to recolonize the crop field as observed in hoverflies and tachinids (Inclán et al., 2016; Sutherland, Sullivan \& Poppy, 2001). They are also regarded as hotspots for other beneficial insects including ground beetles as an indicator species (Yu \& Liu, 2006). Attractiveness of the flowers and presence of nectar are reported to be the major factors 
208 Whiteflies are an example of one taxon found to be effectively controlled by parasitoids that 209 were enhanced as a result of the floral nectar of non-crop vegetation around bean fields ( 210 Hernandez, Otero \& Manzano, 2013). Non-crop habitats within arable lands thus significantly 211 influence the abundance and diversity of natural enemies. From the literature reviewed, it was 212 found even a very small area (tens of square metres) of non-crop habitat had a significant effect 213 on the population of ground dwelling spiders (Knapp \& Řezáč, 2015; Pluess et al., 2010; Jung et 214 al., 2008) and carabid beetles (Knapp \& Řezáč, 2015; Marasas, Sarandón \& Cicchino, 2010; 215 Werling \& Gratton, 2008). Contradictory findings of a much weaker influence of non-crop 216 vegetation on spider populations were reported by D'Alberto, Hoffmann \& Thomson (2012), 217 where other factors like crop characteristics (annual vs perennial) and regional differences 218 appeared to play a larger role. Arthropod populations in field annual crops are highly dependent 219 on the surrounding non-crop vegetation because of the periodic disturbances that occur within 220 the field crop unlike the perennial plants where there is less disturbance. Another study by 221 Noordijk et al. (2010) reported on the influence of the field margin age to invertebrate population 222 where predators were found to decrease with increase in the age of the field margin as a result of 223 decrease in plant species and species evenness. Generally, many natural enemies are enhanced 224 by timely availability of three key resources: prey as a food resource, floral resources as 225 additional food and shelter habitats and overwintering sites in case of disturbances (Ramsden et 226 227 al., 2014). Some invertebrates move from the field margin to the field crop during the growing season when there is abundant food resources and later back to the margin when the resources are scarce or due to agronomic disturbances (Girard et al., 2011). This highlights the importance 229 of margin vegetation as alternative shelter and food resource to beneficial insects around crop 230 land.

Additionally, some field margin plants have pesticidal properties which apart from repelling the insect pests in the field, may also be extracted and used as biopesticides and sprayed to the crops to manage pests as reported by Mkenda et al. (2015). The advantage of natural pesticides from plant origin is that they are less likely to harm non-target organisms and the environment in general, particularly due to their low persistence in soil and on surfaces and lower toxicity 237 (Amoabeng et al., 2013; Mkenda et al., 2015; Mkindi et al., 2017; Tembo et al., 2018). Many 
239 compared with synthetic pesticides (Isman, 2006; Kamanula et al., 2010; Prakash, Rao \&

240 Nandagopal, 2008; Stevenson et al., 2012; Stevenson, Isman \& Belmain, 2017). Therefore,

241 establishing field margins with pesticidal plants is an added advantage that may be particularly

242 beneficial to resource-poor farmers in smallholder or subsistence systems.

243

244 Microbial enemies of insect pests in the field margin were also studied in addition to the natural 245 enemies. The transmission of the entomopathogenic fungus (Pandora neoaphidis) in aphids was 246 significantly higher in fields with margins containing several plant species compared with those 247 with just one plant species ( Baverstock, Clark \& Pell, 2008; Baverstock et al. 2012). In addition, 248 entomopathogenic fungi are more abundant in soils of organic farms as compared with 249 conventional farms with no significant difference in their field margins (Klingen, Eilenberg \& 250 Meadow, 2002). Field margins can act as refuge areas during pesticide application in 251 conventionally managed fields and they should be considered as potential habitats to enhance 252 populations of natural enemies in the field for pest control.

253

254

\subsubsection{Enhancement of insect pollinators}

256

257

258

259

260

261

262

263

264

265

266

267

268

269

Pollinators play an important role in ensuring high yield through pollination services they provide. The most common pollinators studied across the literature reviewed were honey bees (Apis spp.), hoverflies, beetles, moths, butterflies and non-Apis bees. The importance of field margin vegetation to pollination was modelled in monoculture cropping systems and the models predicted that pollinator abundance in the margin would increase with the availability of different floral resources (Rands \& Whitney, 2010). Butterflies were found to benefit from the grassy field margin as their potential corridors in agricultural landscapes with increased pollination service (Delattre et al., 2010). This is because field margins can act as corridors for pollinators to increase their pollination services (Altieri, 1999).

Generally, pollinators are more attracted by the flowering plants rich in nectar and pollen along the field margins compared with non-flower margin plants (Barbir et al., 2015; Carvell et al., 2007; Ricou et al., 2014; Bäckman \& Tiainen, 2002), though preferences for certain resources do exist among different species. For example, Apis bees and non-Apis bees are reported to differ in terms of their preferences to floral resources and foraging distance (Rands \& Whitney, 2011;

PeerJ reviewing PDF | (2019:06:38726:2:0:NEW 17 Oct 2019) 
270 Rollin et al., 2013). A study by Kütt et al. (2016) found linear habitats such as field margins and 271 road verges to be less effective in providing quality flower-based ecosystem services because 272 they were low in species richness as compared with permanent grasslands. According to 273 Denisow \& Wrzesien (2015), pollination services benefit from margin flower plants located at a 274 distance of less than $1000 \mathrm{~m}$, or if the field area is less than 10 ha. Availability of floral resources 275 for nectar provision close to cropped land enhances pollinator abundance, with associated 276 increased pollination service. The type of field margin, whether cropped or uncropped, may also 277 influence the insect population in such habitats because of the differences in plant species 278 composition. For example, uncropped field margins with several naturally regenerated 279 wildflower plant species harboured more bumblebees and honey bees as compared with cropped 280 margins (Kells, Holland \& Goulson, 2001). This shows the need for more research on the 281 influence of different margin characteristics to pollinators and the value of pollination service to crop yield where such studies are limited.

283

\subsubsection{Increased survival of bird species}

285 Some bird species which have been already identified as threatened species were observed in the 286 field margin of agricultural lands in Europe (Wuczyński et al. 2014), flagging the importance of margin habitats. Several measures have been put in place to conserve the rare and endangered bird species, including non agri-biodiversity programs like Agri-Environment Schemes (AES) (Carvell et al., 2007; Field et al., 2007; Marshall, West \& Kleijn, 2006; Merckx et al., 2009); Kleijn et al., 2001; Tarmi, Helenius \& Hyvönen, 2011; Smith et al., 2008; Walker et al., 2007). However, the majority of AES are not performing well on biodiversity conservation and enhancing ecosystems services because many of them have considered the entire field and primarily the crop area, with less attention focused on the field margins (Wiggers et al., 2016). There is a need to combine both AES and proper field margin management to conserve bird population and diversity (Kuiper et al., 2013; Wiggers et al., 2016).

297 The benefits of the field margins to the survival of bird chicks are reported by several studies 298 (Giacomo \& Casenave, 2010; Kleijn et al., 2001; Kuiper et al., 2013; Vickery, Carter \& Fuller, 299 2002; Wilson et al., 2010). This is because a large percentage of the plant species that are used as nesting sites are present in the field margin as compared with the field centre in temperate arable 
301 farms. The increased plant diversity is associated with increased invertebrate biomass ( Balzan, 302 Bocci \& Moonen, 2016; Hiron et al., 2015; Torretta \& Poggio, 2013; Woodcock et al. 2007) 303 which may be useful food resources for birds ( Douglas, Vickery \& Benton, 2009; Wiggers et al. 304 2015; Ottens et al., 2014; Perkins et al., 2002; Woodcock et al., 2009). It is also reported that 305 most of the field margins that were established and managed to promote beneficial insects are 306 used by bird species as overwintering and refuge habitats (Plush et al., 2013). The optimal age

307 308 309

310

311

312

313

314

315

316

317

318

319

320

\section{1}

322

323

324

325

326

327

328

329

330

331 and size of the field margin are reported to affect the richness and breeding densities of bird species where species richness and territory density increased up to the age of 4 to 6 years of the field margin, thereafter it started to decline (Zollinger et al., 2013). The type of field margin vegetation and their characteristics is another potential factor that may influence bird species (Holt et al., 2010; Lemmers, Davidson \& Butler, 2014; Zuria \& Gates, 2013). Comparison of three types of field margin vegetation classified according to the volume of tall vegetation showed that a tree lined margin supported the highest abundance and diversity of bird species, followed by shrubs and lastly by open (herbaceous margin) habitats (Wuczyński et al., 2011). Set-asides are the most preferred habitats for foraging of birds during breeding as compared with grassland or cereal crop margins (Zollinger et al., 2013). Despite the fact that the level of benefits differ between different types of field margin with different management approaches, presence of a field margin did significantly increase the avian biodiversity in arable farms (Marshall, West \& Kleijn, 2006).

\subsubsection{Enhanced survival of small mammals}

Small mammals studied in the context of field margin and adjacent vegetation include the harvest mouse, Reithrodontomys megalotis (Canády, 2013; Sullivan \& Sullivan ,2006), several mole species (Talpidae) (Zurawska-Seta \& Barczak, 2012), house mouse, Mus musculus (Sullivan \& Sullivan, 2006; Moorman et al., 2013), deer mouse, Peromyscus maniculatus, Great Basin pocket mouse, Perognathus parvus and various vole species (Sullivan \& Sullivan, 2006). These mammals took advantage of the established and well managed field margins that aimed to enhance beneficial insect abundance and diversity. Though they usually feed on crops and, thus, must be primarily considered as pest organisms, in a broader context, they may influence the abundance of vertebrate predators, especially the birds that feed on small mammals, serving as a foundation for many trophic interactions (Korpimaki et al., 2005; Meserve et al., 2003). In 
332 addition to the ecological interaction they serve, they also help to reduce weed infestation in the

333 field by feeding on the undesirable weed seeds (Howe \& Brown, 1999).

334

335 Most studies dealt with omnivorous rodents, but the European mole is an obligate carnivore,

336 feeding on earthworms and other invertebrates in the soil. Thus it is not considered as a crop pest

337 (Lund, 1976). The damage caused by mole is through burrowing activities which leads to

338 molehills that may affect vegetation composition of the area, and cause occasional damage to

339 silage (Atkinson, Macdonald \& Johnson, 1994). Consequently, it is considered a pest more in

340 ornamental and amenity contexts than agriculture.

341

\section{$342 \quad 3.1 .5$ Promoting soil macrofauna and organic matter decomposition}

343 Above-ground biodiversity was most commonly studied while only 5\% of papers, all of which

344 were from Europe, considered the effect of field margin management on soil macrofauna such as

345 earthworms (Crittenden et al., 2015; Nuutinen, Butt \& Jauhiainen, 2011; Roarty \& Schmidt

3462013 ). Earthworms are affected by agricultural disturbances such as tillage as it influences soil

347 moisture and, over a long time scale, organic matter (Kuntz et al., 2013; Pelosi et al., 2014;

348 Smith et al., 2008) both of which determine habitat favourability for terrestrial annelids. Several

349 studies (Crittenden et al., 2015; Nuutinen, Butt \& Jauhiainen, 2011) reported an increase in

350 earthworm numbers in the field margin strips with reduced tillage as compared with adjacent

351 arable farms. In general, most of the studies reported that field margin management increased

352 underground soil macrofauna population in comparison with arable lands.

353

354 Other groups of soil organisms that were enhanced by field margin management include soil

355 predators, herbivores and detritivores in different taxonomic groups as Haplotaxida, Isopoda,

356 Chilopoda, Diplopoda, and Coleoptera (Smith et al., 2008; Anderson et al., 2013). The age of the

357 field margin was also reported to influence soil detritivore communities, where richness and

358 diversity was positively related with the age of the field margin (Noordijk et al., 2010). The

359 biodiversity, conservation and functional values of soil macrofauna was enhanced by field

360 margins that were established and managed with the aim of increasing the arthropod population

361 in arable farmlands (Smith et al., 2008). This shows the existence of multiple benefits of field

362 margin plants and the need to maximize such benefits. 
364 Soil biodiversity loss as a result of the expansion, intensification and mechanization of

365

366

367

368

369

370

371

372

373

374

375

376

377

378

379

380

381

382

383

384

385

386

387

388

389

390

391

392

393

agriculture has been recognised as a major challenge to sustainability (Pulleman et al., 2012).

The soil ecosystem includes many decomposer taxa that are key to soil formation and structure and play a significant role in nutrient cycling with clear consequences for plant growth and soil carbon storage (Aislabie \& Deslippe, 2013). In intensive agricultural lands, the densities of soil organisms can be low due to use of agrochemicals and frequent agricultural disturbances, with deleterious effects of decomposition of soil organic matter (Coleman et al., 2002). A comparative study of litter decomposition by soil macrofauna revealed increased activity of soil organisms with increased litter decomposition along the field margins with less disturbance compared with the more disturbed areas (Smith et al., 2009). Field margins are, therefore, providing a contribution to both below and above ground populations of organisms, but undisturbed field margins have higher values in this respect.

\subsubsection{Reduced soil erosion and nutrient loss}

Though soil erosion is a natural process, it can be exacerbated by agricultural intensification that turns it into a major environmental challenge (Uri, 2000). While the rate of soil erosion in farming systems is very high it remains lower in well managed field margins and uncultivated areas (Pimentel et al., 1995). According to Zheng (2006), changes in vegetation composition like conversion of natural or semi natural habitats to crop land greatly influence soil erosion processes. Soil erosion leads to decreased soil nutrients which are important in plant growth thus affecting agriculture production (Lal, 2015). Apart from on-farm effects, soil erosion can have off-farm effects as well, including sedimentation in other areas and water pollution especially if the source is a cultivated area with agro chemical inputs (Uri, 2000; Van Oost et al., 2007). Soil erosion is severe in intensively cultivated land with high tillage practices, intensive chemical inputs and monoculture systems (Jonsson et al., 2012; Meehan et al., 2011; Robinson \& Sutherland, 2002) due to loosening of the soil particles, rendering the surface susceptible to wind and rainfall erosion (Pimentel et al., 1995). The soil erosion in intensively managed agriculture land can be reduced through enhanced soil infiltration (a process in which water on the ground surface enters the soil) which can be achieved through vegetative field margins (Ali \& Reineking, 2016; Zheng, 2006). Other measures that can also be employed to reduce soil erosion 
394 include conservation agriculture based on crop rotation (Sun et al., 2018), mulching (Lalljee, 395 2013), and cover crops (Durán Zuazo et al., 2006; Lal, 2015).

396

397 Field margins are considered effective in eliminating offsite erosion by trapping the sediments 398 that otherwise could have been loaded in the lowland areas including water bodies (Duzant et al., 399 2010; Sheppard et al., 2006; Uri, 2000). This is also supported by Tsiouris et al. (2002) that, 400 most of the fertilizer applied on wheat crops were filtered at the field margins leading to 401 eutrophication of the margin habitats. They reduce the speed of surface runoff and increase soil 402 infiltration depending on the characteristics of the field margin plants and the slope of the land.

403 Different field margin types with different management levels and inclines are reported to have a 404 potential influence of mitigating soil erosion (Ali \& Reineking 2016). In intensively managed 405 landscapes, riparian buffer zones (vegetated areas near water ways) play a similar role of 406 filtering agricultural pollutants that could otherwise enter into water bodies thereby affecting the 407 life of aquatic organisms and other associated ecosystem services.

408

\subsection{Influence of field margin and non-crop vegetation on insect pests and plant viruses}

410 Apart from supporting several beneficial insects and other ecosystem services, field margins 411 have an influence on insect pest populations. They may provide habitat and food resources for 412 both insect pests and their natural enemies in agricultural systems. Therefore, an understanding 413 of their ecological interactions including prey-predator interactions, habitat preferences and 414 mobility, as well as their impact on crop production is important for proper management of the 415 field margins (Tindo et al., 2009). Fruit flies such as Drosophila suzukii (Diptera: Drosophilidae) 416 are among the most studied insect pests of fruits and have several non-crop plant hosts. 417 Consequently, a better understanding of fruit flies' host ranges among plants of the field margin 418 is essential for effective control strategies (Arnó et al., 2016; Kenis et al., 2016; Diepenbrock, 419 Swoboda-Bhattarai \& Burrack, 2016). Unlike fruit flies, spider mites in the Tetranychus genus 420 have a narrower host range; nonetheless, their presence in the field crop was similarly found to 421 be associated with the non-crop host plants around the farmland (Ohno et al., 2010).

422 Consequently, concerning crops affected by this pest, thought must be given to whether potential 423 hosts are present among the field margin vegetation. 
425 One such example is the case of scale insects on cassava and the infestation dynamics with 426 respect to non-crop vegetation. The insects (Stictococcus vayssierei: Stictococcidae) were 427 recorded from several field margin host plants including both native and exotic plant species of 428 the Congo basin (Tindo et al., 2009). Thus, field margin plants could be argued to increase the 429 risk of pest outbreaks on the crop in this case. There is thus a strong need to establish and 430 manage the field margin with plant species that selectively enhance the natural enemies and 431 leave the crop less susceptible to insect pests. However, most of the studies that investigated the 432 effect of well managed field margin vegetation on both beneficial and pest insects reported 433 improved biological control of pest species with few, if any, observations of field margins 434 promoting pest issues (Atakan, 2010; Balzan, Bocci \& Moonen, 2016; Balzan \& Moonen 2014; 435 Eyre et al., 2011; Fusser et al., 2016; Holland et al., 2008). For example, aphid densities in 436 broccoli plots surrounded by bare margin were found to be more than four times the aphid 437 densities in plots surrounded by mixed weedy vegetation (Banks, 2000). This emphasizes the 438 importance of the presence of diverse vegetation in field margins for biological control of insect 439 pests in the field. The presence of prey in non-crop habitats such as field margins may promote 440 the natural enemy population and hence biological control in the field crop. This is in agreement 441 with the study by Bianchi \& Werf (2004) who found the availability of non-pest aphids in the 442 non-crop habitats leads to conservation of ladybirds for enhanced biological control. Thrips, 443 aphids and stink bugs damage was reported to be reduced as a result of increased insect natural 444 enemies in different field margin vegetation (Eyre et al., 2011; Alhmedi et al., 2011 and Pease \& 445 Zalom, 2010 respectively). Other insect pests like moth larvae (Balzan \& Moonen, 2014) and 446 olive psyllids (Paredes et al., 2013) were also found to be effectively managed through enhanced 447 biological control attributed to the non-crop vegetation diversity. It is further reported that more 448 than $90 \%$ of cereal aphids were effectively controlled in fields with wide margins by flying 449 predators (Holland et al., 2008). Further studies on the effect of wildflower strips that were 450 established at the field margin for enhancing beneficial insect population reported no effect on

452

453 The information that some field margin plants may be the most preferred host of some pest 454 species or plant disease vector is useful for selection of the most appropriate species of field 
455 margin plants for a given system. There are some cases where field margin vegetation is unable 456 to enhance the biological control process due to some factors as summarized in Table 1 below; 457

\section{Table 1}

459

460 Field margin plants can also be used as trap crops of insect pests, useful in reducing pest 461 populations from the main crop in the field (Balzan \& Moonen, 2014). Trap crops are plants 462 grown for the purpose of attracting and concentrating the damaging organisms like insect pests 463 and prevent them from reaching the target crop (Hokkanen, 1991; Shelton \& Badenes-Perez,

464 465 466 467 468 469 470 471

472 In addition to the influence of the field margin vegetation on insect pests, assessment of how 473 they may act as reservoirs of plant diseases like alfalfa mosaic virus and cucumber mosaic virus 474 and bean infection incidence was conducted by Mueller, Groves \& Gratton (2012). The study 475 reported less influence of the alfalfa mosaic virus from the margin plants to bean crop and no 476 477 478 479 480 481 482 483 484 485 2006). These trap crops can either be planted in rows within the main crop or planted as field margin plants. In this case, proper selection of border plants is essential as also reported by Schröder et al. (2015) in which border plants were used to attract aphids from the field crop and thus reduced viral infection into the field. A particularly well documented example of the importance of margin plant selection is that of push-pull studies where the insect pests are pushed away from the main crop using a repellent intercrop, and on to the trap crop at the margin (Cook, Khan \& Pickett, 2007).

association was observed between cucumber mosaic virus in the non-crop and bean infestation in the field. Insect pests are also known to be vectors of several plant diseases, especially those which are caused by virus and bacteria (Manandhar \& Hooks, 2011). For example, aphids are the main vector in the spread of virus that cause plant disease. Movement behaviour of alate aphids that is aided by wind increases the spreading of the virus and it is often high near the edge of the field as compared with the field centre (Alderz, 1974; DiFonzo et al., 1996; Perring et al., 1992). Therefore, manipulation of the field margin by planting an alternate crop that acts as a screen around the main crop has been found to be effective in crop protection against non-persistent viral diseases (Damicone et al., 2007). The effectiveness of the border plants in managing the spread of disease depends on several factors including the height of the border plants in relation 
486 to the main crop. The spread pattern of the virus and the level of preference between the border

487 plant and the main crop by the disease vector may also affect the rate of spread of the disease 488 (Fereres, 2000). The border plant may act as a sink or as a physical barrier to the plant virus. As 489 a sink this may be where the infective vector loses the virus when probing non-crop plant species 490 after landing on border plants, by cleansing the mouth parts and reducing the spread of the virus 491 into the adjacent main crop (DiFonzo et al., 1996). As a physical barrier this is where the tall 492 border plants simply reduce the possibility of the aphids landing on the adjacent main crop 493 (Fajinmi \& Odebode, 2010). Table 2 below summarizes some of plant borders that were found to 494 be effective in reducing the spread of plant viral diseases into the main crop.

495

496 Table 2

497

498

499

\subsection{Influence of field margin and non-crop vegetation on weed infestation in the field}

500

Field margin and non-crop vegetation can become weeds if they spread into the field crop. Many farmers fear weed infestation from the margin to the field crop, a belief which is often not

501 supported by evidence (Mante \& Gerowitt, 2009). Reberg-Horton et al. (2011) found no

502 evidence of field margin Amaranthus retroflexus, Cyperus esculentus, Urochloa platyphylla,

503 Ipomoea sp., Digitaria sanguinalis, Mollugo verticilliata, Lamium amplexicaule, Sida spinosa or

504 Senna abtusifolia spreading to adjacent maize (Zea mays L.) or peanut (Arachis hypogaea L.)

505 fields in USA. The type of field margin, plant composition (including their dispersal traits) and

506

507

508

509

510

511

512

513

514

515

516 distance to the field crop are important factors to consider on whether field margin plants will have an influence on weed infestation in the field. However, different weed species may respond differently to these factors, therefore necessitating the need for an understanding of the specific weed functional traits for effective management (Reberg-Horton et al., 2011). For example, the seeds of anemochorous species which are adapted to wind dispersal may disperse only over a short distance (Feldman \& Lewis, 1990) though spreading of field margin plant seeds that are adapted to wind dispersal is thought to be high and over long distance compared with plant species with no specialized dispersal structure.

515 Nevertheless, the presence of weeds within the crop is regarded as one of the ways to enhance biodiversity in agro ecosystems ( Clough, Kruess \& Tscharntke, 2007). However, challenges 
517 stemming from the competition with crops as well as difficulties during harvesting, especially if 518 mechanized, may arise. From the literature reviewed, a major observation from several studies 519 was that weed dissemination into the field largely depends on the type of margin and the way it 520 is maintained throughout the year. De Cauwer et al. (2008) reported on the importance of sown 521 field margin, which are managed through removal of the cuttings in suppression of weed 522 spreading into the field. Similar findings on the importance of sown field margins with proper 523 management for weed control are reported (West, Marshall \& Arnold, 1997; Bokenstrand, 524 Lagerlo \& Torstensson, 2004, Boutin et al., 2001). This being the case, it can be concluded that 525 field margin plants are not necessarily the source of weed infestation into the field, and that for 526 weed control, the establishment and management practices on the fields matter most. Major 527 benefits of field margin vegetation as well as possible unintended consequences and mitigation 528 measures are summarised in Figure 3.

529

530

Figure 3: Potential benefits and dis-benefits derived from field margin vegetation

531

532

\subsection{Agronomic and management factors influencing field margin plant composition}

533 The various management techniques of the field margin and farming operations in the adjacent 534 field have an impact on both field margin flora and fauna composition. Field margin 535 establishment by fencing, application of sown flower mixtures or natural regeneration after the 536 soil is tilled with rotating blades or rotavator (Fritch et al., 2011; Huallacháin et al., 2014) and 537 their structural connectivity ( Fridley, Senft \& Peet, 2009; Kang et al., 2013) determine their 538 vegetation structure and plant diversity. Field margins established through sowing seed mixtures 539 led to the highest diversity of flora and fauna, especially in highly intensified land (Fritch et al., 540 2011). Subsequent management such as cutting (De Cauwer et al., 2008), grazing or mowing 541 (Coulson et al., 2001; Fritch et al., 2011), coppicing, trimming and pollarding (Deckers, Hermy

$542 \&$ Muys, 2004) and other techniques including agrochemical input applications ( Schmitz, Hahn $543 \&$ Brühl, 2014a) have been found to influence the floral species composition as a result of 544 disturbance or changes to the soil nutrient content. Field margins may also be affected by weed 545 invasion, if it alters their vegetation structure and composition depending on establishment and 546 management measures employed (Bokenstrand, Lagerlo \& Torstensson, 2004; De Cauwer et al., 547 2008; Reberg-Horton et al., 2011; West, Marshall \& Arnold, 1997). Other factors influencing the 
548 vegetation structure and composition at the field margin include the ecological and

549 biogeographical context of the area, as well as their historical seedbanks. Field margins have 550 more seedbanks and hence are more species rich compared with the field centre (Jose-Maria \& 551 Sans, 2011).

552

553 Likewise, farming activities adjacent to the field margins such as the application of herbicides

554 (Boutin, Elmegaard \& Kjaer, 2004; Riemens et al., 2009), pesticides and fertilizers (Schmitz, 555 Schäfer \& Brühl, 2013; Schmitz, Schäfer \& Brühl, 2014b) can be considered potential 556 disturbances and may adversely affect the margin flora structure and composition. The effect of 557 fertilizers and herbicides significantly affected the occurrence and frequency of several light

558 feeder plant species that require less nitrogen and other nutrients leading to low diversity while 559 few heavy feeders (plant species with high demand of nitrogen and other nutrients) were

560 favoured by the applied fertilizer ( Schmitz, Hahn \& Brühl, 2014a). Though agrochemical inputs 561 are typically applied in the crop, their effect can be observed in the field margin as a result of 562 direct overspray or spray drift due to their proximity to the field (Firbank et al., 2008). The 563 effects of pesticide drift or overspray are more pronounced in narrow field margins, particularly 564 those less than 3m wide ( Hahn, Lenhardt \& Brühl, 2014). Therefore, field margin plant 565 composition is greatly influenced by the agronomic and management practices which 566 consequently determines faunal composition and hence ecosystem service/disservice.

567

568

\section{Recommendations}

569

570

571

572

573

574

575

576

577

578
Understanding the current status of the biological diversity of field margins and its integration in agriculture, as well as the influence of human agricultural activities on the various organisms within ecosystems is necessary. Only limited information relating to these processes for most tropical areas are available and in some areas the information has been limited to a few sites with relatively similar ecology and management practices (Gardner et al., 2010). Africa particularly is well known in terms of its biodiversity (Duruigbo et al., 2013), though very little research on the importance of biodiversity in agriculture has been carried out in this region. Despite all the reported benefits of field margin vegetation established mostly in American (Amaral et al., 2016; D’Acunto, Semmartin \& Ghersa, 2014; Zuria \& Gates, 2013) and European countries (Guiller et al., 2016; Balzan, Bocci \& Moonen, 2016; Inclán et al., 2016; Knapp \& Řezáč, 2015; Rouabah et 
579 al., 2015), its adoption in other continents is still low (Ndemah, Schulthess \& Nolte, 2006). In

580 view of this, we recommend the following actions.

581

582 First, there is a need for increased research effort on effective techniques for enhancing on-farm

583 biodiversity in order to promote ecosystem services for sustainability in agriculture across

584 regions of the world where such research is still limited. From the literature reviewed, it was

585 observed that field borders that were managed to promote the abundance and diversity of above

586 ground beneficial insects were found to support other organisms like birds, soil macrofauna and

587 small mammals as an additional benefit. Other reported benefits include regulation of water and

588 nutrient content within the soil (Ndemah, Schulthess \& Nolte, 2006), maintaining soil and water

589 quality by preventing erosion and runoff (Ali \& Reineking, 2016; Sheppard et al., 2006) and

590 increased organic matter decomposition by soil organisms (Smith et al., 2009). The multiple

591 benefits arising from field margins justify the need for more research and promotion of these

592 habitats as part of sustainable agricultural intensification.

593

594 Second, raising awareness among the farmers on the ecological and economic effects associated

595 with the misuse of synthetic pesticides. Many farming communities in developing countries are

596 not aware of the hazards associated with the misuse of synthetic pesticides (Ngowi et al., 2007;

597 Kariathi, Kassim \& Kimanya, 2016). Consequently, they are unknowingly killing the natural

598 enemies of insect pests and disrupting the natural pest regulation service with increased pest

599 resistance to most pesticides. The effects of the pesticides applied on crops extends to the field

600 margin plants due to the proximity of the field margins and the crop land and hence affecting the

601 multiple services derived from the field margin (Firbank et al., 2008). It is therefore

602 recommended that agrochemical inputs should be selectively applied or restricted completely in

603 order to increase the diversity of both flora and fauna in agricultural landscapes.

604

605 Third, purposive efforts towards adoption of field margin establishment and management among

606 the farmers should be employed. One of the obstacles existing among the farmers in the adoption

607 of new technology is the fear that it might interfere with their normal farming practices, as well

608 as the establishment cost of the technology (Wilson \& Hart, 2000). However, extensive field

609 margins are among the conservation measures that once established requires less efforts in 
610 maintaining for multiple benefits. Two barriers in some regions may be insufficient knowledge

611 on the ecological benefits of field margins and poor knowledge related to the design of

612 appropriate field margins (Junge et al., 2009; Mante \& Gerowitt, 2009; Morris, Mills \&

613 Crawford, 2000). These knowledge gaps have led to some difficulties in the acceptance of the

614 intervention among the farmers. Social learning and economic incentives such as reduced

615 production cost, more yield, market value or value-added environmental outcome are some of

616 the factors that guarantee wide adoption of an innovation.

617

618 Fourth, fulfilling the potential of ecological benefits of semi natural habitats around the farm

619 land for improved agriculture and environment requires involvement of various stakeholders

620 (who may vary depending on country) such as farmers, local authorities, researchers, policy

621 makers, NGOs, charities and land or estate owners in the discovery of the scientific knowledge

622 for easy adoption. Understanding of their personal, social and economic dynamics in the context

623 of innovation adoption is essential.

624

\section{Conclusions}

626 From the literature reviewed, the majority of studies demonstrate that field margin and non-crop

627 vegetation around agricultural lands can provide various benefits including pest control, crop 628 pollination, reduced offsite erosion, organic matter decomposition and nutrient cycling as well as

629 enhancement of rare and endangered species, both above and below ground organisms. Several

630 functional groups of beneficial organisms were reported to benefit from field margin and non-

631 crop vegetation; the most commonly studied were natural enemies, birds, pollinators, soil

632 macrofauna and small mammals. However, some of the field margin plants were reported to host

633 detrimental pests, a major ecosystem dis-service, leading to increased pest infestation in the field.

634 We also identify other factors that are associated with ineffective pest control of field margin

635 vegetation such as lack of natural enemies in the area, intraguild predation, poor dispersal of the

636 natural enemies to the field crop and the overall quality of the field margin vegetation. Therefore,

637 the promotion of field margin plants that selectively enhance the population of beneficial

638 organisms, together with integration of other techniques like use of non-susceptible crops and

639 crop diversification through intercrop would be desirable for sustainability in agriculture. 
641 Though many studies on the role of field margin and non-crop vegetation have been conducted,

642 geographic distribution of the studies is highly skewed. The studies were largely conducted in

643 some countries, especially in Western Europe, but are very limited in number and scope in many

644 tropical countries. The limited research taking place on these semi natural habitats in the tropics

645 may be due to the lack of research funds and poor knowledge on the ecological benefits of these

646 habitats in the agriculture sector in low-income and smallholder farming systems. This calls for

647 the need to raise awareness on the economic and ecological benefits of the semi natural habitats

648 around agricultural fields for sustainable agriculture in areas where farm biodiversity has been

649 given less attention.

650

651 Acknowledgements

652 We thank Charles Sturt University librarians for their support in this study by providing free

653 access to the Scopus and Web of Science databases which were used to access the literature

654 reviewed.

655

\section{References}

657 Aislabie J, Deslippe JR. 2013. Soil microbes and their contribution to soil services. Ecosystem

658 services in New Zealand-conditions and trends. Manaaki Whenua Press, Lincoln, New

659 Zealand, pp.143-161.

660 Alderz WC, 1974. Wind effects on spread of watermelon mosaic virus 1 from local virus sources 661 to watermelon. Journal of Economic Entomology 67:361-364 DOI:10.1093/jee/67.3.361.

662 Alhmedi A, Haubruge E, D’Hoedt S, Francis F (2011). Quantitative food webs of herbivore and 663 related beneficial community in non-crop and crop habitats. BioControl 58:103-112

664 DOI:10.1016/j.biocontrol.2011.04.005.

665 Ali HE, Reineking B. 2016. Extensive management of field margins enhances their potential for 666

667

668

Alignier A, Baudry J. 2015. Changes in management practices over time explain most variation 669

670

671

672 off-site soil erosion mitigation. Journal of Environmental Management 169:202-209 DOI:10.1016/j.jenvman.2015.12.031. in vegetation of field margins in Brittany, France. Agriculture, Ecosystems \& Environment 211:164-172 DOI:10.1016/j.agee.2015.06.008

Altieri MA. 1999. The ecological role of biodiversity in agroecosystems. Agriculture, Ecosystems \& Environment 74:19-31 DOI:10.1016/S0167-8809(99)00028-6. 
673 Amoabeng BW, Gurr GM, Gitau CW, Nicol HI, Munyakazi L, Stevenson PC. 2013. Tri-trophic 674 insecticidal effects of African plants against cabbage pests. PLoS ONE 8(10): e78651

675 DOI:10.1371/journal.pone.0078651.

676 Amaral DSSL, Venzon M, dos Santos HH, Sujii ER, Schmidt JM, Harwood JD. 2016. Non-crop 677 plant communities conserve spider populations in chili pepper agroecosystems. BioControl 678 103:69-77 DOI:10.1016/j.biocontrol.2016.07.007.

679 Anderson A, Carnus T, Helden AJ, Sheridan H, Purvis G. 2013. The influence of conservation 680 field margins in intensively managed grazing land on communities of five arthropod trophic 681 682 683 684 685 686 687 688 689 690 691

692 693 694 695 696 697 698 699 700 701 702 703 groups. Insect Conservation and Diversity 6:201-211 DOI:10.1111/j.17524598.2012.00203.x.

Arnó J, Solà M, Riudavets J, Gabarra R. 2016. Population dynamics, non-crop hosts, and fruit susceptibility of Drosophila suzukii in Northeast Spain. Journal of Pest Science 89:713-723 DOI:10.1007/s10340-016-0774-3.

Atakan E. 2010. Influence of weedy field margins on abundance patterns of the predatory bugs Orius spp. and their prey, the western flower thrips (Frankliniella occidentalis), on faba bean. Phytoparasitica 38:313-325 DOI:10.1007/s12600-010-0105-9.

Atkinson RPD, Macdonald DW, Johnson PJ. 1994. The status of the European mole Talpa europaea L. as an agricultural pest and its management. Mammal Review 24:73-90 DOI:10.1111/j.1365-2907.1994.tb00136.x.

Bäckman JPC, Tiainen J. 2002. Habitat quality of field margins in a Finnish farmland area for bumblebees (Hymenoptera: Bombus and Psithyrus). Agriculture, Ecosystems \& Environment 89:53-68 DOI:10.1016/S0167-8809(01)00318-8.

Balzan MV, Bocci G, Moonen AC. 2016. Landscape complexity and field margin vegetation diversity enhance natural enemies and reduce herbivory by Lepidoptera pests on tomato crop. BioControl 61:141-154 DOI:10.1007/s10526-015-9711-2.

Balzan MV, Moonen AC. 2014. Field margin vegetation enhances biological control and crop damage suppression from multiple pests in organic tomato fields. Entomologia Experimentalis et Applicata 150:45-65 DOI:10.1111/eea.12142.

Banks JE. 2000. Effects of Weedy Field Margins on Myzus Persicae (Hemiptera : Aphididae) in a Broccoli Agroecosystem. Pan-Pacific Entomologist 76:95-101.

Barbir J, Badenes-Pérez FR, Fernández-Quintanilla C, Dorado J. 2015. Can floral field margins 
704

705

706

707

708

709

710

711

712

713

714

715

716

717

718

719

720

721

722

723

724

725

726

727

728

729

730

731

732

733

734

improve pollination and seed production in coriander Coriandrum sativum L. (Apiaceae)? Agricultural and Forest Entomology 17:302-308 DOI:10.1111/afe.12108.

Baverstock J, Clark SJ, Pell JK. 2008. Effect of seasonal abiotic conditions and field margin habitat on the activity of Pandora neoaphidis inoculum on soil. Journal of Invertebrate Pathology 97:282-290 DOI:10.1016/j.jip.2007.09.004.

Baverstock J, Torrance MT, Clark SJ, Pell JK. 2012. Mesocosm experiments to assess the transmission of Pandora neoaphidis within simple and mixed field margins and over the crop-margin interface. Journal of Invertebrate Pathology 110:102-107

DOI:10.1016/j.jip.2012.02.012.

Bianchi FJJA, Wäckers FL. 2008. Effects of flower attractiveness and nectar availability in field margins on biological control by parasitoids. BioControl 46:400-408

DOI:10.1016/j.biocontrol.2008.04.010.

Bianchi FJJA, Booij CJH, Tscharntke T. 2006. Sustainable pest regulation in agricultural landscapes : a review on landscape composition, biodiversity and natural pest control. Proceedings of the Royal Society 273: 1715-1727 DOI:10.1098/rsbp.2006.3530.

Bianchi FJJA, Van Der Werf W. 2004. Model evaluation of the function of prey in non-crop habitats for biological control by ladybeetles in agricultural landscapes. Ecological Modelling 171:177-193 DOI:10.1016/j.ecolmodel.2003.08.003.

Bischoff A, Pollier A, Lamarre E, Salvadori O, Cortesero AM, Le Ralec,A, Jaloux B. 2016. Effects of spontaneous field margin vegetation and surrounding landscape on Brassica oleracea crop herbivory. Agriculture, Ecosystems \& Environment 223:135-143 DOI:10.1016/j.agee.2016.02.029

Blumenthal D, Jordan N. 2001. Weeds in field margins: A spatially explicit simulation analysis of Canada thistle population dynamics. Weed Science 49:509-519 DOI:10.1614/00431745(2001)049[0509:WIFMAS]2.0.CO;2.

Bokenstrand A, Lagerlo FJ, Torstensson PR. 2004. Establishment of vegetation in broadened field boundaries in agricultural landscapes. Agriculture, Ecosystems \& Environment 101: 21-29 DOI:10.1016/S0167-8809(03)00275-5

Boutin C, Jobin B, Bélanger L, Choinière L. 2001. Comparing weed composition in natural and planted hedgerows and in herbaceous field margins adjacent to crop fields. Canadian Journal of Plant Science 81: 313-324 DOI:10.4141/P00-048. 
735 Boutin C, Elmegaard N, Kjaer C. 2004. Toxicity testing of fifteen non-crops plants species with 736 six herbicides in a greenhouse experiment: Implications for risk assessment. Ecotoxicology $737 \quad 13: 349-369$.

738

739

740

741

742

743

744

745

746

747

748

749

750

751

752

753

754

755

756

757

758

759

760

761

762

763

764

765

Bowie MH, Klimaszewski J, Vink CJ, Hodge S, Wratten SD. 2014. Effect of boundary type and season on predatory arthropods associated with field margins on New Zealand farmland. New Zealand Journal of Zoology 41:268-284 DOI:10.1080/03014223.2014.953552

Burgio G, Ferrari R, Pozzati M, Boriani L. 2004. The role of ecological compensation areas on predator populations: An analysis on biodiversity and phenology of Coccinellidae (Coleoptera) on non-crop plants within hedgerows in Northern Italy. Bulletin of Insectology 57:1-10.

Canády A. 2013. Nest dimensions and nest sites of the harvest mouse (Micromys minutus pallas, 1771) from slovakia: A case study from field margins. Zoology and Ecology 23:253-259 DOI:10.1080/21658005.2013.853492.

Carvell C, Meek WR, Pywell RF, Goulson D, Nowakowski M. 2007. Comparing the efficacy of agri-environment schemes to enhance bumble bee abundance and diversity on arable field margins. Journal of Applied Ecology 44: 29-40 DOI:10.1111/j.1365-2664.2006.01249.x.

Clough Y, Kruess A, Tscharntke T. 2007. Local and landscape factors in differently managed arable fields affect the insect herbivore community of a non-crop plant species. Journal of Applied Ecology 44: 22-28 DOI: 10.1111/j.1365-2664.2006.01239.x.

Coleman DC, Fu S, Hendrix P, Crossley DAJ. 2002. Soil foodwebs in agroecosystems: impacts of herbivory and tillage management. European Journal of Soil Biology 38:21-28 DOI:10.1016/S1164-5563(01)01118-9.

Cook SM, Khan ZR, Pickett J.A. 2007. The use of push-pull strategies in integrated pest management. Annual Review of Entomology 52:375-400

DOI:10.1146/annurev.ento.52.110405.091407.

Coulson SJ, Bullock JM, Stevenson MJ, Pywell RF. 2001. Colonization of grassland by sown species: dispersal versus microsite limitation in responses to management. Journal of Applied Ecology 38: 204-216 DOI:10.1046/j.1365-2664.2001.00585.x.

Crittenden SJ, Huerta E, de Goede RGM, Pulleman MM. 2015. Earthworm assemblages as affected by field margin strips and tillage intensity: An on-farm approach. European Journal of Soil Biology 66:49-56 DOI:10.1016/j.ejsobi.2014.11.007. 
766 D’Acunto L, Semmartin M, Ghersa CM. 2014. Uncropped field margins to mitigate soil carbon

767 losses in agricultural landscapes. Agriculture, Ecosystems \& Environment 183:60-68

768 DOI:10.1016/j.agee.2013.10.022.

769 D'Alberto CF, Hoffmann AA, Thomson LJ. 2012. Limited benefits of non-crop vegetation on

$770 \quad$ spiders in Australian vineyards: Regional or crop differences? BioControl 57: 541-552

771 DOI:10.1007/s10526-011-9435-x.

772 Damicone JP, Edelson JV, Sherwood JL, Myers LD, Motes JE. 2007. Effects of border crops and

773

774

775

776

777

778

779

780

781

782

783

784

785

786

787

788

789

790

791

792

793

794

795

796 intercrops on control of cucurbit virus diseases. Plant Disease 91:509-516 DOI:10.1094/ PDIS-91-5-0509.

De Cauwer B, Reheul D, Nijs I, Milbau A. 2008. Management of newly established field margins on nutrient-rich soil to reduce weed spread and seed rain into adjacent crops. Weed Research 48:102-112 DOI:10.1111/j.1365-3180.2007.00607.x.

Deckers B, Hermy M, Muys B. 2004. Factors affecting plant species composition of hedgerows: relative importance and hierarchy. Acta Oecologica 26: 23-37 DOI:10.1016/j.actao.2004.03.002.

Delattre T, Pichancourt JB, Burel F, Kindlmann P. 2010. Grassy field margins as potential corridors for butterflies in agricultural landscapes: A simulation study. Ecological Modelling 221:370-377 DOI:10.1016/j.ecolmodel.2009.10.010.

Denisow B, Wrzesien M. 2015. The importance of field-margin location for maintenance of food niches for pollinators. Journal of Apicultural Science 59:27-37 DOI:10.1515/jas-20150002.

Diepenbrock LM, Swoboda-Bhattarai KA, Burrack HJ. 2016. Ovipositional preference, fidelity, and fitness of Drosophila suzukii in a co-occurring crop and non-crop host system. Journal of Pest Science 89:761-769 DOI:10.1007/s10340-016-0764-5.

DiFonzo CD, Ragsdale DW, Radcliffe EB, Gudmestad,NC, Secor GA. 1996. Crop borders reduce potato virus Y incidence in seed potato. Annals of Applied Biology 129:289-302 DOI:10.1111/j.1744-7348.1996.tb05752.x.

Ditner N, Balmer O, Beck J, Blick T, Nagel P, Luka H. 2013. Effects of experimentally planting non-crop flowers into cabbage fields on the abundance and diversity of predators. Biodiversity and Conservation 22:1049-1061 DOI:10.1007/s10531-013-0469-5. Douglas DJT, Vickery JA, Benton TG. 2009. Improving the value of field margins as foraging 
797

798

799

800

801

802

803

804

805

806

807

808

809

810

811

812

813

814

815

816

817

818

819

820

821

822

823

824

825

826

habitat for farmland birds. Journal of Applied Ecology 46:353-362 DOI:10.1111/j.13652664.2009.01613.x.

Durán Zuazo VH, Martínez JRF, Pleguezuelo CRR, Martínez Raya A, Rodríguez BC. 2006. Soil-erosion and runoff prevention by plant covers in a mountainous area (SE Spain): Implications for sustainable agriculture. Environment 26:309-319 DOI:10.1007/s10669006-0160-4

Duruigbo CI, Okereke-Ejiogu EN, Nwokeji EM, Peter-Onoh CA, Ogwudire VE, Onoh PA. 2013. Integrated remediation strategies for sustaining agrobiodiversity degradation in Africa. IOSR Journal of Agriculture and Veterinary Science 3: 16-23 DOI: 10.9790/2380-0341623.

Duzant JH, Morgan RPC, Wood GA, Deeks LK. 2010. Modelling the Role of Vegetated Buffer Strips in Reducing Transfer of Sediment from Land to Watercourses. Handbook of Erosion Modelling. John Wiley \& Sons, Ltd, pp. 249-262.

Eyre MD, Labanowska-Bury D, White R, Leifert C. 2011. Relationships between beneficial invertebrates, field margin vegetation, and thrip damage in organic leek fields in eastern England. Organic Agriculture 1:45-54 DOI:10.1007/s13165-010-0004-X.

Eyre MD, Sanderson RA, McMillan SD, Critchley CNR. 2016. Crop cover the principal influence on non-crop ground beetle (Coleoptera, Carabidae) activity and assemblages at the farm scale in a long-term assessment. Bulletin of Entomological Research 106:242-248 DOI:10.1017/S0007485315001054.

Fajinmi AA, Odebode CA. 2010. Evaluation of maize/pepper intercropping model in the management of pepper veinal mottle virus, genus Potyvirus, family Potyviridae on cultivated pepper (Capsicum annuumL.) in Nigeria. Archives of Phytopathology and Plant Protection 43:1524-1533 DOI:10.1080/03235400802583677.

Falloon P, Falloon P, Powlson D, Smith P. 2004. Managing field margins for biodiversity and carbon sequestration: a Great Britain case study. Soil Use and Management 20:240-247 DOI:10.1079/SUM2004236.

Feldman SR, Lewis JP. 1990. Output and dispersal of propagules of Carduus acanthoides L. Weed Research 30:161-169 DOI:10.1111/j.1365-3180.1990.tb01700.x.

Fereres A. 2000. Barrier crops as a cultural control measure of non-persistently transmitted 
827

828

829

830

831

832

833

834

835

836

837

838

839

840

841

842

843

844

845

846

847

848

849

850

851

852

853

854

855

856

857

aphid-borne viruses. Virus Research 71:221-231 DOI:10.1016/S0168-1702(00)00200-8.

Field RG, Gardiner T, Mason CF, Hill J. 2007. Agri-environment schemes and butterflies: The utilisation of two metre arable field margins. Biodiversity and Conservation 16:465-474 DOI:10.1007/s10531-005-6202-2.

Firbank LG, Petit S, Smart S, Blain A, Fuller RJ. 2008. Assessing the impacts of agricultural intensification on biodiversity: a British perspective. Philosophical Transaction of Royal Society B - Biological Sciences 363: 777-787 DOI:10.1098/rstb.2007.2183.

Fischer C, Schlinkert H, Ludwig M, Holzschuh A, Gallé R, Tscharntke T, Batáry P. 2013. The impact of hedge-forest connectivity and microhabitat conditions on spider and carabid beetle assemblages in agricultural landscapes. Journal of Insect Conservation 17: 10271038 DOI:10.1007/s10841-013-9586-4.

Fridley AJD, Senft AR, Peet RK. 2009. Vegetation structure of Field Margins and Adjacent Forests in Agricultural Landscapes of the North Carolina Piedmont. Castanea 74:327-339. DOI:10.2179/08-057R1.1.

Fritch RA, Sheridan H, Finn JA, Kirwan L, hUallacháin DÓ. 2011. Methods of enhancing botanical diversity within field margins of intensively managed grassland: A 7-year field experiment. Journal of Applied Ecology 48:551-560 DOI:10.1111/j.13652664.2010.01951.x.

Fusser MS, Pfister SC, Entling MH, Schirmel J. 2016. Effects of landscape composition on carabids and slugs in herbaceous and woody field margins. Agriculture, Ecosystems \& Environment 226:79-87 DOI:10.1016/j.agee.2016.04.007.

Gardner TA, Barlow J, Sodhi NS, Peres CA. 2010. A multi-region assessment of tropical forest biodiversity in a human-modified world. Biological Conservation 143(10):2293-2300 DOI:10.1016/j.biocon.2010.05.017.

Gerland P, Raftery AE, Sevcikova H, Li N, Gu D, Spoorenberg T, Alkema L, Fosdick BK, Chunn J, Lalic N, Bay G, Buettner T, Heilig GK, Wilmoth J. 2014. World population stabilization unlikely this century. Science 346: 234-237 DOI:10.1126/science.1257469.

Giacomo AS, Casenave JL. 2010. Use and importance of crop and field-margin habitats for birds in a Neotropical agricultural ecosystem. The Condor 112:283-293 DOI:10.1525/cond.2010.090039.

Girard J, Baril A, Mineau P, Fahrig L. 2011. Carbon and nitrogen stable isotope ratios differ 
858

859

860

861

862

863

864

865

866

867

868

869

870

871

872

873

874

875

876

877

878

879

880

881

882

883

884

885

886

887

888

among invertebrates from field crops, forage crops, and non-cropped land uses. Écoscience 18:98-109 DOI:10.2980/18-2-3390.

Guiller C, Affre L, Albert CH, Tatoni T, Dumas E. 2016. How do field margins contribute to the functional connectivity of insect-pollinated plants? Landscape Ecology 31:1747-1761 DOI:10.1007/s10980-016-0359-9.

Gurr GM, Wratten SD, Luna JM. 2003. Multi-function agricultural biodiversity: pest management and other benefits. Basic Applied Ecology 4:107-116 DOI:10.1078/14391791-00122

Gurr GM, Lu Z, Zheng X, Xu H, Zhu P, Chen G, Yao X, Cheng J, Zhu Z, Catindig JL, Villareal S, Chien HV, Cuong LQ, Channoo C, Chengwattana N, Lan LP, Hai LH, Chaiwong J, Nicol HI, Perovic DJ, Wratten SD, Heong, K. L. 2016. Multi-country evidence that crop diversification promotes ecological intensification of agriculture. Nature Plants 2:22-25 DOI:10.1038/NPLANTS.2016.14.

Hackett M, Lawrence A. 2014. Multifunctional role of field margins in arable farming. Report for European Crop Protection Association by Cambridge Environmental Assessments, Report Number CEA.1118

Hahn M, Lenhardt PP, Brühl CA. 2014. Characterization of field margins in intensified agroecosystems-why narrow margins should matter in terrestrial pesticide risk assessment and management. Integrated Environment Assessment and Management 10:456-462 DOI:10.1002/ieam.1535.

Hatt S, Boeraeve F, Artru S, Dufrêne M, Francis F. 2018. Spatial diversification of agroecosystems to enhance biological control and other regulating services: An agroecological perspective. Science of Total Environment 621:600-611 DOI:10.1016/j.scitotenv.2017.11.296.

Hernandez LM, Otero JT, Manzano MR. 2013. Biological control of the greenhouse whitefly by Amitus fuscipennis: Understanding the role of extrafloral nectaries from crop and non-crop vegetation. BioControl 67:227-234 DOI:10.1016/j.biocontrol.2013.08.003.

Hiron M, Berg Å, Eggers S, Berggren Å, Josefsson J, Pärt T. 2015. The relationship of bird diversity to crop and non-crop heterogeneity in agricultural landscapes. Landscape Ecology 30:2001-2013 DOI:10.1007/s10980-015-0226-0.

Hokkanen HMT. 1991. Trap cropping in pest management. Annual Review of Entomology 
889

890

891

892

893

894

895

896

897

898

899

900

901

902

903

904

905

906

907

908

909

910

911

912

913

914

915

916

917

918

919

36:119-38 DOI:10.1146/annurev.en.36.010191.001003.

Holland JM, Oaten H, Southway S, Moreby S. 2008. The effectiveness of field margin enhancement for cereal aphid control by different natural enemy guilds. BioControl 47: 7176 DOI:10.1016/j.biocontrol.2008.06.010.

Holt CA, Atkinson PW, Vickery JA, Fuller RJ. 2010. Do field margin characteristics influence songbird nest-site selection in adjacent hedgerows? Bird Study 57:392-395 DOI:10.1080/00063651003674938.

Howe HF, Brown JS. 1999. Effects of birds and rodents on synthetic tallgrass communities. Ecology 80:1776-1781 DOI:10.2307/176568

Huallacháin DÓ, Anderson A, Fritch R, McCormack S, Sheridan H, Finn JA. 2014. Field margins: A comparison of establishment methods and effects on hymenopteran parasitoid communities. Insect Conservation and Diversity 7:289-307 DOI:10.1111/icad.12053.

Inclán DJ, Dainese M, Cerretti P, Paniccia D, Marini L. 2016. Spillover of tachinids and hoverflies from different field margins. Basic Applied Ecology 17:33-42 DOI:10.1016/j.baae.2015.08.005.

Isman MB. 2006. Botanical insecticides, deterrents, and repellents in modern agriculture and an increasingly regulated world. Annual Review of Entomology 51: 45-66 DOI:10.1146/annurev.ento.51.110104.151146.

Jayasena KW, Randles JW. 1985. The effects of insecticides and a plant barrier row on aphid populations and spread of bean yellow mosaic potyvirus and subterranean clover red leaf luteovirus in Vicia faba in South Australia. Annals of Applied Biology 107:355-364 DOI:10.1111/j.1744-7348.1985.tb03152.x.

Jonsson M, Buckley HL, Case BS, Wratten SD, Hale RJ, Didham RK. 2012. Agricultural intensification drives landscape context effects on host-parasitoid interaction in agroecosystems. Journal of Applied Ecology 49:706-714 DOI:10.1111/j.13652664.2012.02130.x.

Jose-maria L, Sans FX. 2011. Weed seedbanks in arable fields: effects of management practices and surrounding landscape. Weed Research 51:631-640 DOI:10.1111/j.13653180.2011.00872.x.

Jung MP, Kim ST, Kim H, Lee JH. 2008. Biodiversity and community structure of grounddwelling spiders in four different field margin types of agricultural landscapes in Korea. 
920

921

922

923

924

925

926

927

928

929

930

931

932

933

934

935

936

937

938

939

940

941

942

943

944

945

946

947

948

949

950

Applied Soil Ecology 38:185-195 DOI:10.1016/j.apsoil.2007.10.010.

Junge X, Jacot KA, Bosshard A, Lindemann-Matthies P. 2009. Swiss people's attitudes towards field margins for biodiversity conservation. Journal for Nature Conservation 17:150-159 DOI:10.1016/j.jnc.2008.12.004.

Kamanula J, Sileshi GW, Belmain SR., Sola P, Mvumi BM, Nyirenda GK, Stevenson PC. 2010. Farmers' insect pest management practices and pesticidal plant use in the protection of stored maize and beans in Southern Africa. International Journal of Pest Management 57:41-49 DOI:10.1080/09670874.2010.522264.

Kang W, Hoffmeister M, Martin EA, Steffan-Dewenter I, Han D, Lee D. 2013. Effects of management and structural connectivity on the plant communities of organic vegetable field margins in South Korea. Ecological Research 28: 991-1002 DOI:10.1007/s11284-0131081-6.

Kariathi V, Kassim N, Kimanya M. 2016. Pesticide exposure from fresh tomatoes and its relationship with pesticide application practices in Meru district. Cogent Food and Agriculture 2:1196808 DOI:10.1080/23311932.2016.1196808.

Kells AR, Holland JM, Goulson D. 2001. The value of uncropped field margins for foraging bumblebees. Journal of Insect Conservation 5:283-291.

Kenis M, Tonina L, Eschen R, van der Sluis B, Sancassani M, Mori N, Haye T, Helsen, H. 2016. Non-crop plants used as hosts by Drosophila suzukii in Europe. Journal of Pest Science 89:735-748 DOI:10.1007/s10340-016-0755-6.

Kleijn D, Berendse F, Smit R, Gilissen N. 2001. Agri-environment schemes do not effectively protect biodiversity in Dutch agricultural landscapes. Nature 413:723-725.

Klingen I, Eilenberg J, Meadow R. 2002. Effects of farming system, field margins and bait insect on the occurrence of insect pathogenic fungi in soils. Agriculture, Ecosystems \& Environment 91:191-198 DOI:10.1016/S0167-8809(01)00227-4.

Knapp M, Řezáč M. 2015. Even the smallest non-crop habitat islands could be beneficial: Distribution of carabid beetles and spiders in agricultural landscape. PLOS ONE 10: 1-20 DOI:10.1371/journal.pone.0123052.

Korpimaki E, Norrdahl K, Huitu O, Klemola T. 2005. Predator induced synchrony in population oscillations of coexisting small mammal species. Proceedings of Biological Science 272:193-202 DOI:10.1098/rspb.2004.2860. 
951 Kuiper MW, Ottens HJ, Cenin L, Schaffers AP, van Ruijven J, Koks BJ, Berendse F, de Snoo 952 GR. 2013. Field margins as foraging habitat for skylarks (Alauda arvensis) in the breeding 953 season. Agriculture, Ecosystems \& Environment 170:10-15

954 DOI:10.1016/j.agee.2013.03.001.

955 Kuntz M, Berner A, Gattinger A, Scholberg JM, Mäder P, Pfiffner L. 2013. Influence of reduced 956 tillage on earthworm and microbial communities under organic arable farming.

957 Pedobiologia 56:251-260 DOI:10.1016/j.pedobi.2013.08.005.

958 Kütt L, Lõhmus K, Rammi IJ, Paal T, Paal J, Liira J (2016). The quality of flower-based 959 ecosystem services in field margins and road verges from human and insect pollinator 960 perspectives. Ecological Indicators 70:409-419 DOI:10.1016/j.ecolind.2016.06.009.

961 Lal R. 2015. Restoring soil quality to mitigate soil degradation. Sustainability (Switz) 7:5875$962 \quad 5895$ DOI:10.3390/su7055875.

963 Lalljee B. 2013. Mulching as a mitigation agricultural technology against land degradation in the 964 wake of climate change. International Soil and Water Conservation Research 1:68-74 965 DOI:10.1016/S2095-6339(15)30032-0.

966 Landis DA, Wratten SD, Gurr GM. 2000. Habitat management to conserve natural enemies of 967 arthropod pests in agriculture. Annual Review of Entomology 45:175-201

968 DOI:10.1146/annurev.ento.45.1.175.

969 Lee JC, Menalled FB Landis DA. 2001. Refuge habitats modify impact of insecticide 970 disturbance on carabid beetle communities. Journal of Applied Ecology 38:472-483 971 DOI:10.1046/j.1365-2664.2001.00602.x.

972 Lemmers P, Davidson MM, Butler RC. 2014. Relative abundance of introduced European birds 973 varies with field margin type on arable farms in Canterbury, New Zealand. New Zealand 974 Journal of Zoology 41:203-209 DOI:10.1080/03014223.2014.893893.

975 Lund M. 1976. Control of the European mole, Talpa eruopaea. Proceedings of the 7th $976 \quad$ Vertebrate Pest Conference 32:125-130.

977 Lomer C, Bateman R, Johnson D, Langewald J, Thomas M. 2001. Biological control of locusts 978 and grasshoppers. Annual Review of Entomology 1:667-702

979 DOI:10.1146/annurev.ento.46.1.667

980 Manandhar R, Hooks CR. 2011. Using protector plants to reduce the incidence of Papaya 981 ringspot virus-watermelon strain in zucchini. Environmental Entomology 40:391-398 
982

983

984

985

986

987

988

989

990

991

992

993

994

995

996

997

998

999

1000

1001

1002

1003

1004

1005

1006

1007

1008

1009

1010

1011

1012

\section{DOI:10.1603/EN10229.}

Mante J, Gerowitt B. 2009. Learning from farmers' needs: Identifying obstacles to the successful implementation of field margin measures in intensive arable regions. Landscape and Urban Planning 93:229-237 DOI:10.1016/j.landurbplan.2009.07.010.

Marasas ME, Sarandón SJ, Cicchino A. 2010. Semi-natural habitats and field margins in a typical agroecosystem of the argentinean pampas as a reservoir of carabid beetles. Journal of Sustainable Agriculture 34:153-168 DOI:10.1080/10440040903482563.

Marshall EJP. 2004. Agricultural landscapes: field margin habitats and their interaction with crop production. Journal of Crop Improvement 12:365-404 DOI:10.1300/J411v12n01_05.

Marshall EJP, West TM, Kleijn D. 2006. Impacts of an agri-environment field margin prescription on the flora and fauna of arable farmland in different landscapes. Agriculture, Ecosystems \& Environment 113: 36-44 DOI:10.1016/j.agee.2005.08.036.

Martin-Guay MO, Paquette A, Dupras J, Rivest D. 2018. The new Green Revolution: Sustainable intensification of agriculture by intercropping. Science of Total Environment 615: 767-772 DOI:10.1016/j.scitotenv.2017.10.024.

Martin EA, Reineking B, Seo B, Steffan-Dewenter I. 2013. Natural enemy interactions constrain pest control in complex agricultural landscapes. Proceedings of the National Academy of Sciences of the United States of America 110: 5534-5539.

McNeely JA, Scherr SJ. 2003. Ecoagriculture: strategies for feed the world and save wild biodiversity. Island Press, Washington, DC.

Meehan TD, Werling BP, Landis DA, Gratton C. 2011. Agricultural landscape simplification and insecticide use in the Midwestern United States. Proceedings of the National Academy of Sciences of the United States of America 108:11500-11505.

Meek B, Loxton D, Sparks T, Pywell R, Pickett H, Nowakowski M. 2002. The effect of arable field margin composition on invertebrate biodiversity. Biological Conservation 106:259271 DOI:10.1016/S0006-3207(01)00252-X.

Merckx T, Feber RE, Dulieu RL, Townsend MC, Parsons MS, Bourn NAD, Riordan P, Macdonald DW. 2009. Effect of field margins on moths depends on species mobility: Fieldbased evidence for landscape-scale conservation. Agriculture, Ecosystems \& Environment 129:302-309 DOI:10.1016/j.agee.2008.10.004

Meserve PL, Kelt DA, Milstead WB, Gutie'rrez JR. 2003. Thirteen years of shifting top-down 
1013

1014

1015

1016

1017

1018

1019

1020

1021

1022

1023

1024

1025

1026

1027

1028

1029

1030

1031

1032

1033

1034

1035

1036

1037

1038

1039

1040

1041

1042

1043

and bottom-up control. BioScience 53:633-646 DOI:10.1641/00063568(2003)053[0633:TYOSTA]2.0.CO;2.

Mkenda P, Mwanauta R, Stevenson PC, Ndakidemi P, Mtei K, Belmain SR. 2015. Extracts from field margin weeds provide economically viable and environmentally benign pest control compared to synthetic pesticides. PloS one 10: e0143530

DOI:10.1371/journal.pone.0143530.

Mkindi AG, Mpumi N, Tembo Y, Stevenson PC, Ndakidemi PA, Mtei K, Machunda R, Belmain SR. 2017. Invasive weeds with pesticidal properties as potential new crops. Industrial Crops and Products 110:113 122 DOI:10.1016/j.indcrop.2017.06.002.

Moher D, Liberati A, Tetzlaff J, Altman DG. 2009. Preferred Reporting Items for Systematic Reviews and Meta-Analyses: The PRISMA Statement. PLoS Med 6:e1000097 DOI:10.1371/journal.pmed.1000097.

Moorman CE, Plush CJ, Orr DB, Reberg-Horton C, Gardner B. 2013. Small mammal use of field borders planted as beneficial insect habitat. Wildlife Society Bulletin 37:209-215 DOI:10.1002/wsb.226.

Morris J, Mills J, Crawford IM. 2000. Promoting farmer uptake of agrienvironment schemes: the Countryside Stewardship Arable Options Scheme. Land Use Policy 17:241-254 DOI:10.1016/S0264-8377(00)00021-1.

Mueller EE, Groves RL, Gratton C. 2012. Crop and Non-Crop Plants as Potential Reservoir Hosts of Alfalfa mosaic virus and Cucumber mosaic virus for Spread to Commercial Snap Bean. Plant Disease 96:506-514 DOI:10.1094/PDIS-02-11-0089.

Murphy JF, Mosjidis J, Eubanks MD, Masiri J. 2008. Inter-row soil cover to reduce incidence of aphid-borne viruses in pumpkin. International Journal of Vegetable Science 14:290-303 DOI:10.1080/19315260802212555.

Ndemah R, Schulthess F, Nolte C. 2006. The effect of grassy field margins and fertilizer on soil water, plant nutrient levels, stem borer attacks and yield of maize in the humid forest zone of Cameroon. Annales de La Societe Entomologique de France 42:461-470

DOI:10.1080/00379271.2006.10697480.

Ngowi AVF, Mbise TJ, Ijani ASM, London L, Ajayi OC. 2007. Pesticides use by smallholder farmers in vegetable production in Northern Tanzania. Crop Protection 26: 1617 DOI:10.1016/j.cropro.2007.01.008. 
1044 Noordijk J, Musters CJM, van Dijk J, de Snoo GR. 2010. Invertebrates in field margins:

1045 Taxonomic group diversity and functional group abundance in relation to age. Biodiversity 1046 and Conservation 19:3255-3268 DOI:10.1007/s10531-010-9890-1.

1047 Nuutinen V, Butt KR, Jauhiainen L. 2011. Field margins and management affect settlement and

1048

1049

1050

1051

1052

1053

1054

1055

1056

1057

1058

1059

1060

1061

1062

1063

1064

1065

1066

1067

1068

1069

1070

1071

1072

1073

1074 spread of an introduced dew-worm (Lumbricus terrestris L.) population. Pedobiologia 54:S167-S172 DOI:10.1016/j.pedobi.2011.07.010.

Ohno S, Miyagi A, Ganaha-Kikumura T, Gotoh T, Kijima K, Ooishi T, Moromizato C, Haraguchi D, Yonamine K, Uezato T. 2010. Non-crop host plants of Tetranychus spider mites (Acari: Tetranychidae) in the field in Okinawa, Japan: Determination of possible sources of pest species and inference on the cause of peculiar mite fauna on crops. Applied Entomology and Zoology 45:465-475 DOI:10.1303/aez.2010.465.

Olson DM, Wäckers FL. 2007. Management of field margins to maximize multiple ecological services. Journal of Applied Ecology 44:13-21 DOI:10.1111/j.1365-2664.2006.01241.x.

Ordway EM, Asner GP, Lambin EF. 2017. Deforestation risk due to commodity crop expansion in sub-Saharan Africa. Environmental Research Letters 12:044015 DOI:10.1088/17489326/aa6509.

Ottens HJ, Kuiper MW, Flinks H, van Ruijven J, Siepel H, Koks BJ, Berendse F de Snoo GR. 2014. Do field margin enrich the diet of the Eurasian Skylark Alauda arvensis on Intensive farmland? Ardea 102:161-174 DOI:10.5253/arde.v102i2.a6.

Paredes D, Cayuela L, Gurr GM, Campos M. 2013. Effect of non-crop vegetation types on conservation biological control of pests in olive groves. PeerJ 1: e116 DOI:10.7717/peerj.116

Pease CG, Zalom FG. 2010. Influence of non-crop plants on stink bug (Hemiptera: Pentatomidae) and natural enemy abundance in tomatoes. Journal of Applied Entomology 134:626-636 DOI:10.1111/j.1439-0418.2009.01452.x.

Pelosi C, Pey B, Hedde M, Caro G, Capowiez Y, Guernion M, Peigne J, Piron D, Bertrand M, Cluzeau D. 2014. Reducing tillage in cultivated fields increases earthworm functional diversity. Applied Soil Ecology 83:79-87 DOI:10.1016/j.apsoil.2013.10.005.

Perkins AJ, Whittingham MJ, Morris AJ, Bradbury RB. 2002. Use of field margins by foraging yellowhammers Emberiza citrinella. Agriculture, Ecosystems \& Environment 93:413-420 DOI:10.1016/S0167-8809(01)00306-1. 
1075 Perner J, Malt S. 2003. Assessment of changing agricultural land use: response of vegetation, 1076 ground-dwelling spiders and beetles to the conservation of arable land into grassland. 1077 Agriculture, Ecosystems \& Environment 98:169-181 DOI:10.1016/S0167-8809(03)0007910783.

1079 Perring TM, Farrar CA, Mayberry K, Blua MJ. 1992. Research reveals pattern of cucurbit virus 1080 spread. California Agriculture 46:35-40.

1081 Pimentel D, Harvey C, Resosudarmo P, Sinclair K, Kurz D, McNair M, Crist S, Shpritz L, Fitton 1082 1083 L, Saffouri R, Blair R. 1995. Environmental and economic costs of soil erosion and conservation benefits. Science 267:1117e1123 DOI:10.1126/science.267.5201.1117.

1084

Pluess T, Opatovsky I, Gavish-Regev E, Lubin Y, Schmidt-Entling MH. 2010. Non-crop habitats 1085 in the landscape enhance spider diversity in wheat fields of a desert agroecosystem. 1086 Agriculture, Ecosystems \& Environment 137:68-74 DOI:10.1016/j.agee.2009.12.020.

1087

Plush CJ, Moorman CE, Orr DB, Reberg-Horton C. 2013. Overwintering sparrow use of field 1088 1089 borders planted as beneficial insect habitat. Journal of Wildlife Management 77:200-206 DOI:10.1002/jwmg.436.

1090

Prakash A, Rao J, Nandagopal V. 2008. Future of botanical pesticides in rice, wheat, pulses and vegetables pest management. Journal of Biopesticides 1:154-169.

Pulleman M, Creamer R, Hamer U, Helder J, Pelosi C, Pérès G, Rutgers M (2012). Soil biodiversity, biological indicators and soil ecosystem services - an overview of European approaches. Current Opinion in Environmental Sustainability 4:529-538 DOI:10.1016/j.cosust.2012.10.009

Ramsden MW, Menéndez R, Leather SR, Wäckers F. 2014. Optimizing field margins for biocontrol services: The relative role of aphid abundance, annual floral resources, and overwinter habitat in enhancing aphid natural enemies. Agriculture, Ecosystems \& Environment 199:94-104 DOI:10.1016/j.agee.2014.08.024.

Rands SA, Whitney HM. 2010. Effects of pollinator density-dependent preferences on field margin visitations in the midst of agricultural monocultures: A modelling approach. Ecological Modelling 221:1310-1316DOI:10.1016/j.ecolmodel.2010.01.014. pollinator success. PLOS ONE 6:10 DOI:10.1371/journal.pone.0025971. 
1106

1107

1108

1109

1110

1111

1112

1113

1114

1115

1116

1117

1118

1119

1120

1121

1122

1123

1124

1125

1126

1127

1128

1129

1130

1131

1132

1133

1134

1135

1136

2011. Influence of field margin type on weed species richness and abundance in conventional crop fields. Renewable Agriculture and Food Systems 26:127-136 DOI:10.1017/S1742170510000451.

Ricou C, Schneller C, Amiaud B, Plantureux S, Bockstaller C. 2014. A vegetation-based indicator to assess the pollination value of field margin flora. Ecological Indicators 45:320331 DOI:10.1016/j.ecolind.2014.03.022.

Riemens MM, Dueck T, Kempenaar C, Lotz LAP, Kropff MJJ. 2009. Sublethal effects of herbicides on the biomass and seed production of terrestrial non-crop plant species, influenced by environment, development stage and assessment date. Environmental Pollution 157:2306-2313 DOI:10.1016/j.envpol.2009.03.037.

Rigat M, Bonet MÁ, Garcia S, Garnatje T, Vallés J. 2009. Ethnobotany of food plants in the high river Ter valley (Pyrenees, Catalonia, Iberian Peninsula): Non-crop food vascular plants and crop food plants with medicinal properties. Ecology of Food and Nutrition 48:303-326 DOI:10.1080/03670240903022320.

Roarty S, Schmidt O. 2013. Permanent and new arable field margins support large earthworm communities but do not increase in-field populations. Agriculture, Ecosystems \& Environment 170:45-55 DOI:10.1016/j.agee.2013.02.011.

Robinson RA, Sutherland WJ. 2002. Post-war changes in arable farming and biodiversity in Great Britain. Journal of Applied Ecology 39:157-176 DOI:10.1046/j.13652664.2002.00695.x.

Rollin O, Bretagnolle V, Decourtye A, Aptel J, Michel N, Vaissière BE, Henry M. 2013.

Differences of floral resource use between honey bees and wild bees in an intensive farming system. Agriculture, Ecosystems \& Environment 179:78-76

DOI:10.1016/j.agee.2013.07.007.

Rouabah A, Villerd J, Amiaud B, Plantureux S, Lasserre-Joulin F. 2015. Response of carabid beetles diversity and size distribution to the vegetation structure within differently managed field margins. Agriculture, Ecosystems \& Environment 200:21-32 DOI:10.1016/j.agee.2014.10.011.

Schmitz J, Hahn M, Brühl CA. 2014a. Agrochemicals in field margins - An experimental field study to assess the impacts of pesticides and fertilizers on a natural plant community. Agriculture, Ecosystems \& Environment 193:60-69 DOI:10.1016/j.agee.2014.04.025. 
1137 Schmitz J, Schäfer K, Brühl CA. 2013. Agrochemicals in field margins-assessing the impacts of 1138 herbicides, insecticides, and fertilizer on the common buttercup (Ranunculus acris). 1139 Environmental Toxicology and Chemistry 32:1124-1131 DOI:10.1002/etc.2138.

1140 Schmitz J, Schäfer K, Brühl CA. 2014b. Agrochemicals in field margins-Field evaluation of 1141 plant reproduction effects. Agriculture, Ecosystems \& Environment 189:82-91

1142 DOI:10.1016/j.agee.2014.03.007.

1143 Schröder ML, Glinwood R, Webster B, Ignell R, Krüger K. 2015. Olfactory responses of 1144 Rhopalosiphum padi to three maize, potato, and wheat cultivars and the selection of prospective crop border plants. Entomologia Experimentalis et Applicata 157:241-253 DOI:10.1111/eea.12359.

Shelton AM, Badenes-Perez FR. 2006. Concepts and application of crop trapping in pest management. Annual Review of Entomology 51:285-308 DOI:10.1146/annurev.ento.51.110104.150959.

Sheppard SC, Sheppard MI, Long J, Sanipelli B, Tait J. 2006. Runoff phosphorus retention in vegetated field margins on flat landscapes. Canadian Journal of Soil Science 86:871-884 DOI:10.4141/S05-072.

Simmons JN. 1957. Effects of insecticides and physical barriers on field spread of pepper veinbanding mosaic virus. Phytopathology 47:139-145.

Sitzia T, Dainese M, McCollin D. 2014. Environmental factors interact with spatial processes to determine herbaceous species richness in woody field margins. Plant Ecology 215:13231335 DOI:10.1007/s11258-014-0390-3.

Sitzia T, Trentanovi G, Marini L, Cattaneo D, Semenzato P. 2013. Assessment of hedge stand types as determinants of woody species richness in rural field margins. IForest 6:201-208 DOI:10.3832/ifor0749-006.

Smith H, Feber RE, Morecroft MD, Taylor ME, Macdonald DW. 2010. Short-term successional change does not predict long-term conservation value of managed arable field margins. Biological Conservation 143:813-822 DOI:10.1016/j.biocon.2009.12.025. enhance their biodiversity, conservation and functional value for soil macrofauna? Journal of Applied Ecology 45:269-278 DOI:10.1111/j.1365-2664.2007.01433.x.

Smith J, Potts SG, Woodcock BA, Eggleton P. 2009. The impact of two arable field margin 
1168

1169

1170

1171

1172

1173

1174

1175

1176

1177

1178

1179

1180

1181

1182

1183

1184

1185

1186

1187

1188

1189

1190

1191

1192

1193

1194

1195

1196

1197

1198

management schemes on litter decomposition. Applied Soil Ecology 41:90-97

DOI:10.1016/j.apsoil.2008.09.003.

Sorribas J, González S, Domínguez-Gento A, Vercher R. 2016. Abundance, movements and biodiversity of flying predatory insects in crop and non-crop agroecosystems. Agronomy for Sustainable Development 36: 34 DOI:10.1007/s13593-016-0360-3.

Stevenson PC, Isman MB, Belmain SR (2017). Pesticidal plants in Africa: A global vision of new biological control products from local uses. Industrial Crops and Products 110:2-9 DOI:10.1016/j.indcrop.2017.08.034.

Stevenson PC, Kite GC, Lewis GP, Forest F, Nyirenda SP, Belmain SR, Sileshi GW, Veitch NC. 2012. Distinct chemotypes of Tephrosia vogelii and implications for their use in pest control and soil enrichment. Phytochemistry 78:135-146 DOI:10.1016/j.phytochem.2012.02.025.

Street TI, Prentice HC, Hall K, Smith HG, Olsson O. 2015. Removal of woody vegetation from uncultivated field margins is insufficient to promote non-woody vascular plant diversity. Agriculture, Ecosystems \& Environment 201: 1-10 DOI:10.1016/j.agee.2014.11.020.

Sullivan TP, Sullivan DS. 2006. Plant and small mammal diversity in orchard versus non-crop habitats. Agriculture, Ecosystems \& Environment 116:235-243 DOI:10.1016/j.agee.2006.02.010.

Sun L, Wang S, Zhang Y, Li J, Wang X, Wang R, Lyu W, Chen N, Wang Q. 2018. Conservation agriculture based on crop rotation and tillage in the semi-arid Loess Plateau, China: Effects on crop yield and soil water use. Agriculture, Ecosystems \& Environment 251:67-77 DOI:10.1016/j.agee.2017.09.011.

Sutherland JP, Sullivan MS, Poppy GM. 2001. Distribution and abundance of aphidophagous hoverflies ( Diptera : Syrphidae ) in wild flower patches and field margin habitats. Agricultural and Forest Entomology 3:57-64 DOI:10.1046/j.1461-9563.2001.00090.x.

Tarmi S, Helenius J, Hyvönen T. 2011. The potential of cutting regimes to control problem weeds and enhance species diversity in an arable field margin buffer strip. Weed Research 51:641-649 DOI:10.1111/j.1365-3180.2011.00888.x.

Tembo Y, Mkindi AG, Mkenda PA, Mpumi N, Mwanauta R, Stevenson PC, Ndakidemi PA and Belmain SR. 2018. Pesticidal Plant Extracts Improve Yield and Reduce Insect Pests on Legume Crops Without Harming Beneficial Arthropods. Frontiers in Plant Science 9:1425 DOI:10.3389/fpls.2018.01425. 
1199 Tindo M, Hanna R, Goergen G, Zapfack L, Tata-Hangy K, Attey A. 2009. Host plants of 1200 Stictococcus vayssierei Richard (Stictococcidae) in non-crop vegetation in the Congo Basin 1201 and implications for developing scale management options. International Journal of Pest 1202 Management 55:339-345 DOI:10.1080/09670870902934864.

1203 Torretta JP, Poggio SL. 2013. Species diversity of entomophilous plants and flower-visiting 1204 1205 1206 1207 insects is sustained in the field margins of sunflower crops. Journal of Natural History 47:139-165 DOI:10.1080/00222933.2012.742162.

Tsiouris SE, Mamolos AP, Kalburtji KL, Alifrangis D. 2002. The quality of runoff water 1208 89:117-125 DOI:10.1016/S0167-8809(01)00323-1.

United Nations, Department of Economics and Social Affairs (2019). World population prospects (2019): Highlights. https://population.un.org/wpp/Publications/Files/WPP2019 10KeyFindings.pdf.

Uri ND. 2000. Agriculture and the Environment - The Problem of Soil Erosion. Journal of Sustainable Agriculture 16:71-94 DOI:10.1300/J064v16n04_07.

Valin H, Sands RD, Van der Mensbrugghe D, Nelson GC, Ahammad H, Blanc E, Bodirsky B, Fujimori S, Hasegawa T, Havlik P, Heyhoe E, Kyle P, Mason-D'Croz D, Paltsev S, Rolinski S, Tabeau A, van Meij1 H, von Lampe M, Willenbockel D. 2014. The future of food demand: understanding differences in global economic models. Agricultural Economics 45: $51-67$.

Van Oost K, Quine TA, Govers G, De Gryze S, Six J, Harden JW, Ritchie JC, McCarty GW, Heckrath G. 2007. The impact of agricultural soil erosion on the global carbon cycle. Science 318:626e629 DOI:10.1126/science.1145724.

Vickery J, Carter N, Fuller RJ. 2002. The potential value of managed cereal field margins as foraging habitats for farmland birds in the UK. Agriculture, Ecosystems \& Environment 89:41-52 DOI:10.1016/S0167-8809(01)00317-6.

Vickery JA, Feber RE, Fuller RJ. 2009. Arable field margins managed for biodiversity conservation: A review of food resource provision for farmland birds. Agriculture, Ecosystems \& Environment 133:1-13 DOI:10.1016/j.agee.2009.05.012.

Walker KJ, Critchley CNR, Sherwood AJ, Large R, Nuttall P, Hulmes S, Rose R, Mountford JO. 2007. The conservation of arable plants on cereal field margins: An assessment of new agri- 
1230

1231

1232

1233

1234

1235

1236

1237

1238

1239

1240

1241

1242

1243

1244

1245

1246

1247

1248

1249

1250

1251

1252

1253

1254

1255

1256

1257

1258

1259

1260

environment scheme options in England, UK. Biological Conservation 136:260-270 DOI:10.1016/j.biocon.2006.11.026.

Werling BP, Gratton C. 2008. Influence of field margins and landscape context on ground beetle diversity in Wisconsin (USA) potato fields. Agriculture, Ecosystems \& Environment 128:104-108 DOI:10.1016/j.agee.2008.05.007.

West TM, Marshall EJP, Arnold GM. 1997. Can sown field boundary strips reduce the ingress of aggressive field margin weeds? In: Proceedings of the 1997 Brighton Crop Protection Conference-Weeds, Brighton, UK, pp. 985-990.

Wiggers JMR (Hanneke), van Ruijven J, Schaffers AP, Berendse F, de Snoo GR. 2015. Food availability for meadow bird families in grass field margins. Ardea 103:17-26 DOI:10.5253/arde.v103i1.a2.

Wiggers JMRH, van Ruijven J, Berendse F, de Snoo GR. 2016. Effects of grass field margin management on food availability for Black-tailed Godwit chicks. Journal for Nature Conservation 29:45-50 DOI:10.1016/j.jnc.2015.11.001.

Wilson GA, Hart K. 2000. Financial imperative or conservation concern? EU farmers' motivations for participation in voluntary agri-environmental schemes. Environment and Planning A 32:2161-2185 DOI:10.1068/a3311.

Wilson MW, Gittings T, Kelly TC, O'Halloran J. 2010. The importance of non-crop vegetation for bird diversity in Sitka spruce plantations in Ireland. Bird Study 57:116-120 DOI:10.1080/00063650903150676

Woodcock BA, Potts SG, Pilgrim E, Ramsay AJ, Tscheulin T, Parkinson A, Smith REN, Gundrey AL, Brown VK, Tallowin JR. 2007. The potential of grass field margin management for enhancing beetle diversity in intensive livestock farms. Journal of Applied Ecology 44:60-69 DOI:10.1111/j.1365-2664.2006.01258.x.

Woodcock BA, Potts SG, Tscheulin T, Pilgrim E, Ramsay AJ, Harrison-Cripps J, Brown VK, Tallowin JR. 2009. Responses of invertebrate trophic level, feeding guild and body size to the management of improved grassland field margins. Journal of Applied Ecology 46:920929 DOI:10.1111/j.1365-2664.2009.01675.x.

Woodcock BA, Westbury DB, Tscheulin T, Harrison-Cripps J, Harris SJ, Ramsay AJ, Brown VK, Potts SG. 2008. Effects of seed mixture and management on beetle assemblages of arable field margins. Agriculture, Ecosystems \& Environment 125:246-254 
1261

1262 1263

1264

1265

1266

1267

1268

1269

1270

1271

1272

1273

1274

1275

1276

1277

1278

1279

1280

1281

1282

1283

1284

DOI:10.1016/j.agee.2008.01.004.

Wrzesień M, Denisow B. 2016. The effect of agricultural landscape type on field margin flora in South Eastern Poland. Acta Botanica Croatica 75:217-225 DOI:10.1515/botcro-2016-0027.

Wuczyński A, Dajdok Z, Wierzcholska S, Kujawa K. 2014. Applying red lists to the evaluation of agricultural habitat: Regular occurrence of threatened birds, vascular plants, and bryophytes in field margins of Poland. Biodiversity and Conservation 23:999-1017 DOI:10.1007/s10531-014-0649-y.

Wuczyński A, Kujawa K, Dajdok Z, Grzesiak W. 2011. Species richness and composition of bird communities in various field margins of Poland. Agriculture, Ecosystems \& Environment 141:202-209 DOI:10.1016/j.agee.2011.02.031.

Yu Z, Liu Y. 2006. Field margins as rapidly evolving local diversity hotspots for ground beetles (Coleoptera: Carabidae) in Northern China. The Coleopterists Bulletin 60:135-143 DOI:10.1649/854.1.

Zheng FL. 2006. Effect of vegetation changes on soil erosion on the loess plateau. Pedosphere 16:420e427 DOI:10.1016/S1002-0160(06)60071-4.

Zollinger JL, Birrer S, Zbinden N, Korner-Nievergelt F. 2013. The optimal age of sown field margins for breeding farmland birds. Ibis 155: 779-791DOI:10.1111/ibi.12072.

Zurawska-Seta E, Barczak T. 2012. The influence of field margins on the presence and spatial distribution of the european mole Talpa Europaea L. within the agricultural landscape of northern Poland. Archives of Biological Sciences 64:971-980 DOI:10.2298/ABS1203971Z.

Zuria I, Gates JE. 2013. Community composition, species richness, and abundance of birds in field margins of central Mexico: Local and landscape-scale effects. Agroforestry Systems 87:377-393 DOI:10.1007/s10457-012-9558-9. 


\section{Figure 1}

Field margin management practices, undisturbed (A) and disturbed (B).

Undisturbed field margin vegetation around agricultural lands are useful in provision of nectar and habitat for beneficial arthropods thereby enhancing ecosystem services. Disturbed or cleared field margins are less efficient in enhancing beneficial arthropods.

Photo credit: Patrick Ndakidemi

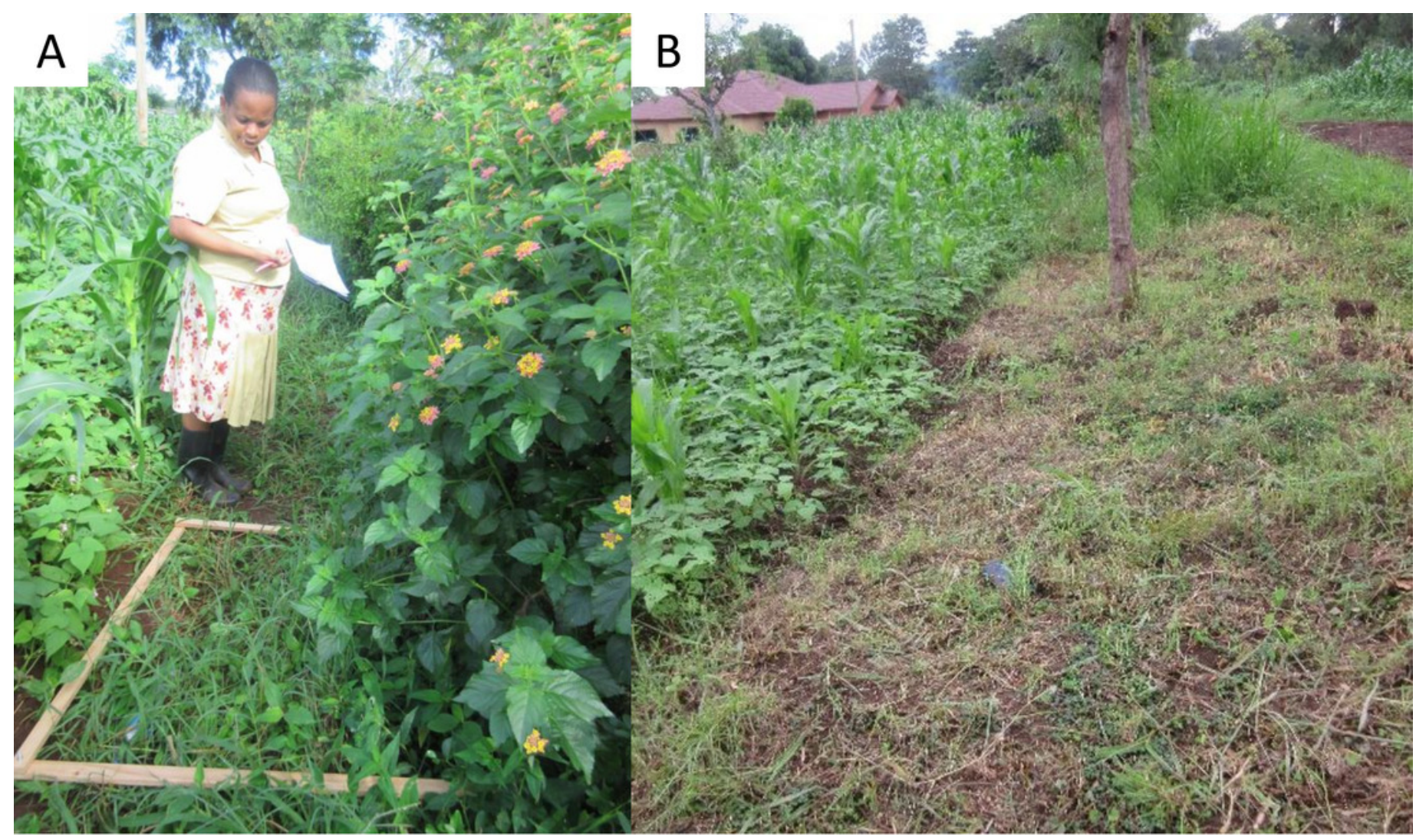


Figure 2

Animal groups that benefit from the field margin and non-cropvegetation around agricultural lands

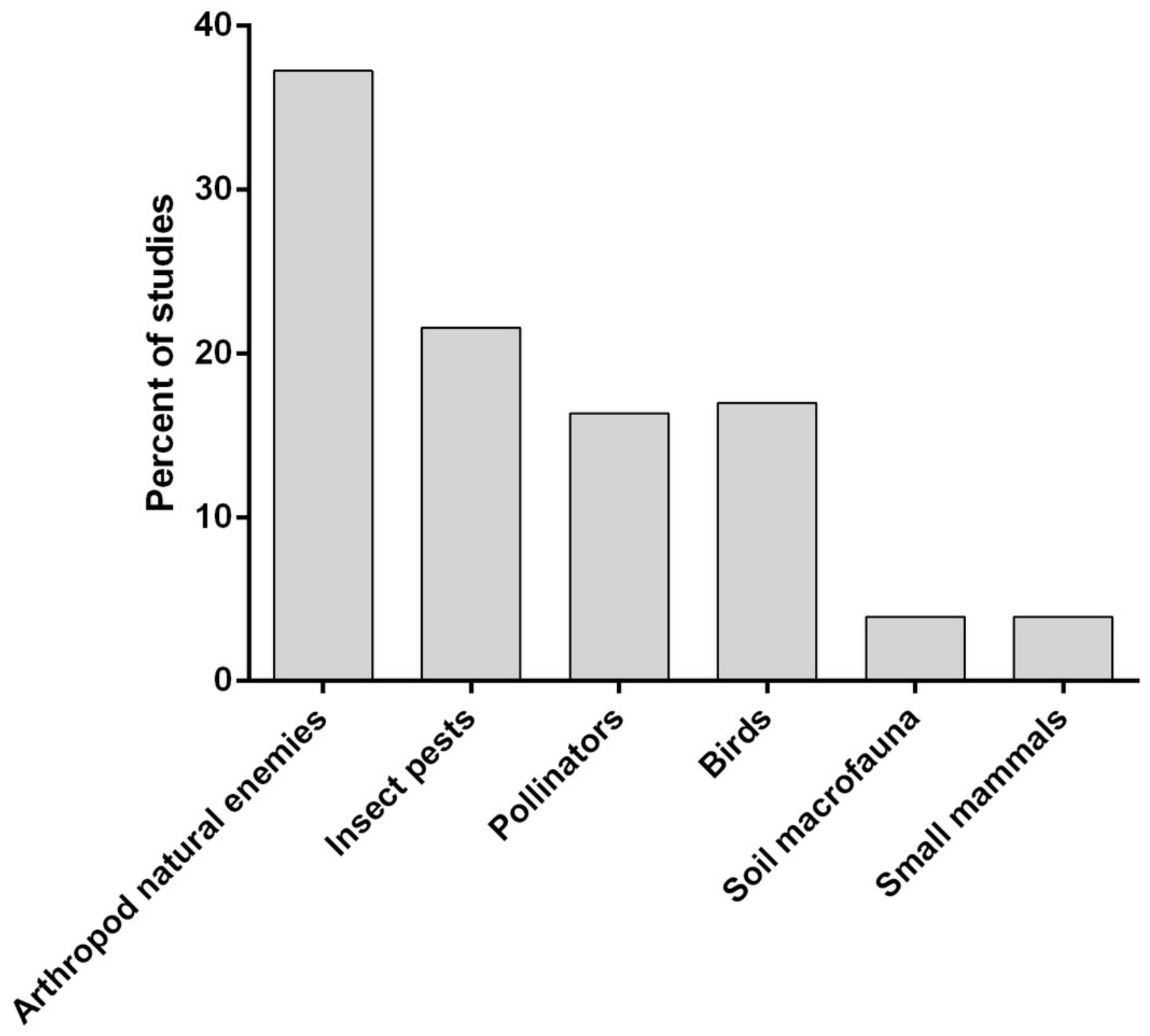

Animal groups 
Figure 3

Potential benefits and dis-benefits derived from field margin vegetation

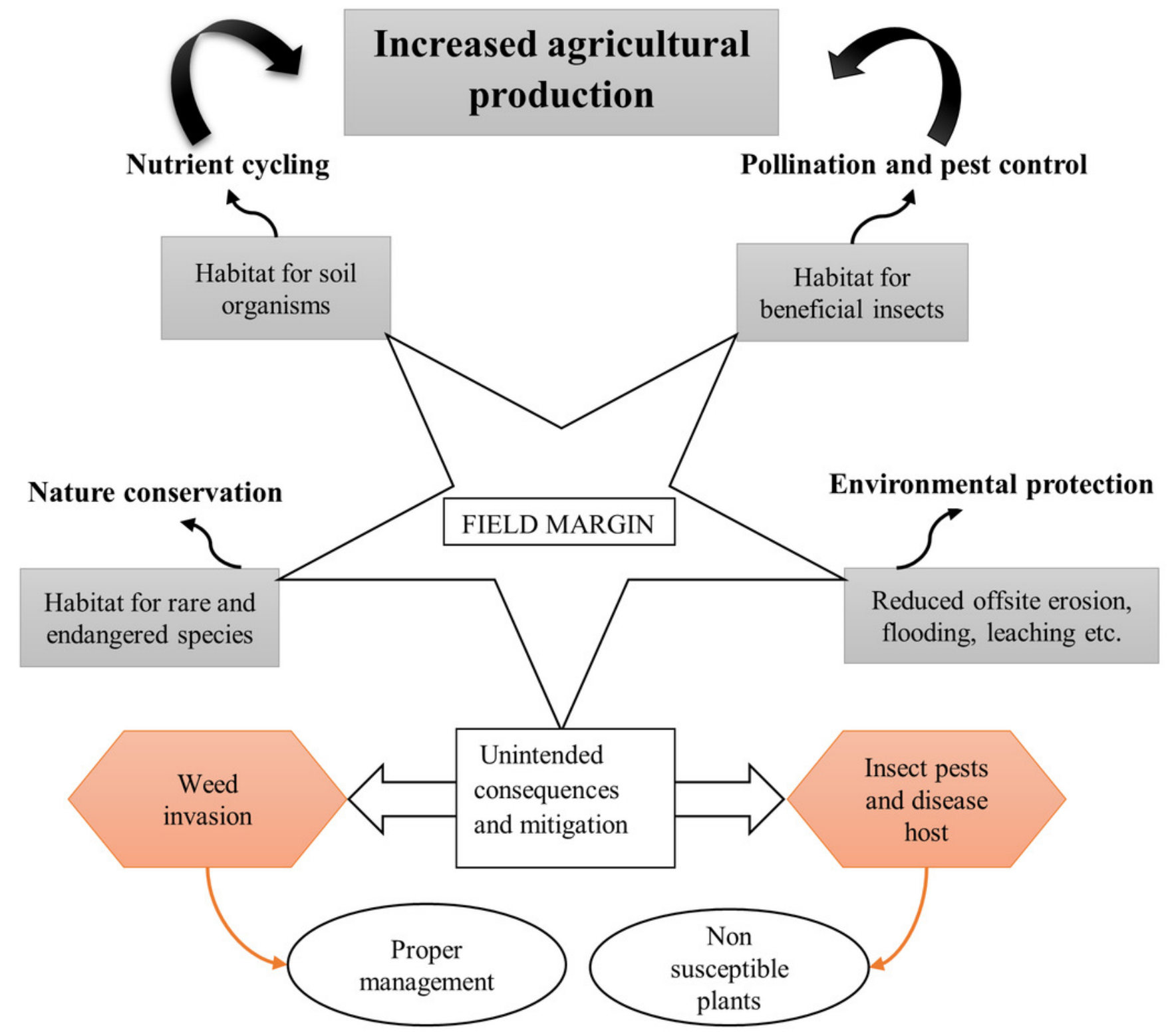




\section{Table 1 (on next page)}

Factors accounting for ineffective pest regulationof field margin vegetation 
1 Table 1: Factors accounting for ineffective pest regulation of field margin vegetation

\begin{tabular}{|c|c|c|c|}
\hline $\begin{array}{l}\text { Influencing } \\
\text { factors }\end{array}$ & Explanation & $\begin{array}{l}\text { Example of } \\
\text { species studied }\end{array}$ & Reference \\
\hline $\begin{array}{l}\text { Lack of effective } \\
\text { natural enemy in } \\
\text { the area }\end{array}$ & $\begin{array}{l}\text { Invasive pest species may arrive in } \\
\text { an area without their biological } \\
\text { control agents, unless they are } \\
\text { introduced in the area where they can } \\
\text { be enhanced by the vegetation } \\
\text { diversity }\end{array}$ & $\begin{array}{l}\text { Migratory } \\
\text { locust, Locusta } \\
\text { migratoria }\end{array}$ & $\begin{array}{l}\text { Lomer et al. } \\
(2001)\end{array}$ \\
\hline $\begin{array}{l}\text { Intraguild } \\
\text { predation }\end{array}$ & $\begin{array}{l}\text { Predation of the biological control } \\
\text { agents by other natural enemies lead } \\
\text { to more pest outbreak regardless of } \\
\text { the vegetation diversity in the area }\end{array}$ & $\begin{array}{l}\text { Insectivorous } \\
\text { birds and } \\
\text { wasps }\end{array}$ & $\begin{array}{l}\text { Martin et al. } \\
(2013)\end{array}$ \\
\hline $\begin{array}{l}\text { Natural enemy } \\
\text { dispersal ability }\end{array}$ & $\begin{array}{l}\text { Field margin vegetation are good in } \\
\text { harbouring the natural enemies, but } \\
\text { poor dispersal of the natural enemies } \\
\text { may lead to ineffective pest control } \\
\text { within the crop land }\end{array}$ & Carabid beetles & $\begin{array}{l}\text { Fischer et al. } \\
\text { (2013) }\end{array}$ \\
\hline $\begin{array}{l}\text { Margins with } \\
\text { non-crop hosts }\end{array}$ & $\begin{array}{l}\text { Host plants (susceptible plants) at the } \\
\text { field margins may provide habitat to } \\
\text { insect pests and act as a source of } \\
\text { pests in the field }\end{array}$ & $\begin{array}{l}\text { Drosophila } \\
\text { suzukii and } \\
\text { Stictococcus } \\
\text { vayssierei }\end{array}$ & $\begin{array}{l}\text { Arnó et al. } \\
(2016) ; \text { Kenis } \\
\text { et al. (2016) } \\
\text { and Tindo et } \\
\text { al. (2009) }\end{array}$ \\
\hline $\begin{array}{lr}\text { Planting } & \text { of } \\
\text { susceptible } & \text { crop } \\
\text { variety } & \end{array}$ & $\begin{array}{l}\text { Planting of susceptible crop varieties } \\
\text { with little or no crop diversification } \\
\text { may lead to high pest infestation } \\
\text { regardless of the presence of margin } \\
\text { vegetation }\end{array}$ & $\begin{array}{l}\text { Pegion pea } \\
\text { (Cajanus } \\
\text { cajan) } \\
\text { genotypes and } \\
\text { maize }\end{array}$ & $\begin{array}{l}\text { Dasbak et al. } \\
(2012) ; \\
\text { Poveda et al. } \\
(2008)\end{array}$ \\
\hline $\begin{array}{l}\text { Field margin with } \\
\text { substitutional } \\
\text { resource }\end{array}$ & $\begin{array}{l}\text { Depends on the degree to which the } \\
\text { alternative resource is } \\
\text { complementary or substitutional for } \\
\text { the prey. This may limit pest control } \\
\text { in the field }\end{array}$ & $\begin{array}{l}\text { Adult lacewing } \\
\text { and aphids }\end{array}$ & $\begin{array}{l}\text { Robinson et al. } \\
\text { (2002) }\end{array}$ \\
\hline $\begin{array}{l}\text { Improved margin } \\
\text { (sown species- } \\
\text { rich margin }\end{array}$ & $\begin{array}{l}\text { Improved (undisturbed) field margin } \\
\text { may provide favourable habitats for } \\
\text { survival and reproduction of some } \\
\text { pests }\end{array}$ & Slugs & $\begin{array}{l}\text { Eggenschwiler } \\
\text { et al. (2013) }\end{array}$ \\
\hline $\begin{array}{l}\text { The quality of } \\
\text { field margin }\end{array}$ & $\begin{array}{l}\text { The quality of plant resource } \\
\text { mediates positive or negative effects }\end{array}$ & $\begin{array}{l}\text { Big-eyed bug } \\
\text { (Geocoris }\end{array}$ & $\begin{array}{l}\text { Eubanks and } \\
\text { Denno (2000) }\end{array}$ \\
\hline
\end{tabular}


plants to pest suppression within the crop punctipes) and land

pea aphids

2 


\section{Table 2 (on next page)}

Reduced spread ofplant viral diseases using border plants as protector plants 
1 Table 2: Reduced spread of plant viral diseases using border plants as protector plants

\begin{tabular}{|c|c|c|c|}
\hline Border plants & Main crop & Disease controlled & Reference \\
\hline Sunflower & Pepper & Potato Virus Y (PVY) & Simmons (1957) \\
\hline Maize & Potatoes & Potato Virus Y (PVY) & Schröder et al. (2015) \\
\hline $\begin{array}{l}\text { Sorghum, soybean } \\
\text { and wheat }\end{array}$ & Potatoes & Potato Virus Y (PVY) & DiFonzo et al. (1996) \\
\hline $\begin{array}{l}\text { Bushclover and sunn } \\
\text { hemp }\end{array}$ & Pumpkin & $\begin{array}{l}\text { Watermelon Mosaic Virus } \\
\text { (WMV) and Papaya } \\
\text { ringspot virus (PRSV) }\end{array}$ & Murphy et al. (2008) \\
\hline Barley & Broad bean & Bean Yellow Mosaic Virus & $\begin{array}{l}\text { Jayasena and Randles } \\
(1985)\end{array}$ \\
\hline $\begin{array}{l}\text { Sorghum, corn and } \\
\text { vetch }\end{array}$ & Peppers & $\begin{array}{l}\text { Cucumber Mosaic Virus } \\
\text { (CMV) and PVY }\end{array}$ & Fereres 2000 \\
\hline Sorghum & Pumpkin & $\begin{array}{l}\text { Watermelon Mosaic Virus } \\
\text { (WMV) and Papaya } \\
\text { ringspot Virus type -W }\end{array}$ & $\begin{array}{l}\text { Damicone et al. } \\
(2007)\end{array}$ \\
\hline
\end{tabular}

